\title{
Iron-Based Catalytically Active Complexes in Preparation of Functional Materials
}

\author{
Katarzyna Rydel-Ciszek ${ }^{1}$ (), Tomasz Pacześniak ${ }^{1}$, Izabela Zaborniak ${ }^{1}{ }^{\circledR}$, Paweł Błoniarz ${ }^{1}{ }^{(0)}$, \\ Karolina Surmacz ${ }^{2}$, Andrzej Sobkowiak ${ }^{1}$ and Paweł Chmielarz ${ }^{1, *(\mathbb{D}}$ \\ 1 Department of Physical Chemistry, Faculty of Chemistry, Rzeszow University of Technology, Al. Powstańców \\ Warszawy 6, 35-959 Rzeszów, Poland; kasiar@prz.edu.pl (K.R.-C.); tompacz@prz.edu.pl (T.P.); \\ i.zaborniak@stud.prz.edu.pl (I.Z.); bloniarz@prz.edu.pl (P.B.); asobkow@prz.edu.pl (A.S.) \\ 2 Doctoral School of Engineering and Technical Sciences, Rzeszow University of Technology, Al. Powstańców \\ Warszawy 8, 35-959 Rzeszów, Poland; d503@stud.prz.edu.pl \\ * Correspondence: p_chmiel@prz.edu.pl; Tel.: +48-17-865-1809
}

Received: 13 November 2020; Accepted: 18 December 2020; Published: 20 December 2020

check for

\begin{abstract}
Iron complexes are particularly interesting as catalyst systems over the other transition metals (including noble metals) due to iron's high natural abundance and mediation in important biological processes, therefore making them non-toxic, cost-effective, and biocompatible. Both homogeneous and heterogeneous catalysis mediated by iron as a transition metal have found applications in many industries, including oxidation, C-C bond formation, hydrocarboxylation and dehydration, hydrogenation and reduction reactions of low molecular weight molecules. These processes provided substrates for industrial-scale use, e.g., switchable materials, sustainable and scalable energy storage technologies, drugs for the treatment of cancer, and high molecular weight polymer materials with a predetermined structure through controlled radical polymerization techniques. This review provides a detailed statement of the utilization of homogeneous and heterogeneous iron-based catalysts for the synthesis of both low and high molecular weight molecules with versatile use, focusing on receiving functional materials with high potential for industrial application.
\end{abstract}

Keywords: iron-based catalysts; oxidation processes; "green" oxidants; homogeneous catalysis; heterogeneous catalysis; controlled radical polymerization

\section{Introduction}

Environmental pollution and climate change make the introduction of "green chemistry" principles into industry one of the most urgent scientific challenges. According to this approach, it is important to reduce the use and generation of substances hazardous to the environment and human health as well as to make industrial manufacturing methods more eco-friendly and cost-effective. In the last decade, iron catalysts have received much attention due to their nontoxic, abundant, and inexpensive qualities. Tetra- and pentadentate iron complexes have found a wide application as catalysts for hydroxylation [1,2], dihydroxylation [3,4], or epoxidation [5-8] of hydrocarbon substrates providing substrates for industrial-scale use, also as switchable materials, in the effective treatment of cancer or catalysts for controlled radical polymerization. The oxidation of organic substrates with high stereo- and regioselectivity by environmentally friendly oxidants, such as dioxygen $\left(\mathrm{O}_{2}\right)$ or hydrogen peroxide $\left(\mathrm{H}_{2} \mathrm{O}_{2}\right)$ catalyzed by bioinspired iron(II) catalysts, are very important from a technological point of view. Oxidizers used in chemicals production are expensive, highly toxic, and environmentally harmful. The use of molecular oxygen or hydrogen peroxide for their oxidation provides biomimetic oxygen activation - analogous to processes produced by nature. Clean technology, and efficient and cost-effective processes are currently desired. In this context, iron catalysts stabilized by nitrogen donor ligands are a good alternative. Iron complexes bearing well-designed $N$ donor ligands have found applications 
as catalysts across multiple fields of research, e.g., homogeneous catalysis, coordination chemistry, or materials science, and can prove their usability as catalysts for industrial processes in organic synthesis, pharmacy, and advanced materials technologies. The range of catalytic activity of discussed iron complexes is not confined to the oxidation processes. These complexes have found the number of applications in polymerization, C-C bond formation, hydrocarboxylation and dehydration reactions, as well as in hydrogenation and reduction reactions. Iron complexes containing $N$ donor ligands were successfully used as photosensitizers in solar cells and in light-driven redox and catalytic processes, owing to their photochemical properties.

Catalysts based on supported metal complexes also deserve attention. The most promising group of precious group metal (PGM)-free electrocatalysts are metal-nitrogen-carbon (Me-N-C) materials, frequently heat-treated. Iron-based ones stand out, owing to good activity and low cost. Nowadays, Fe complexes containing $N$ donor ligands are used for the synthesis of electrocatalysts investigated for oxygen reduction reaction (ORR) [9-12], oxygen evolution reaction (OER) [13,14], hydrogen evolution reaction (HER) [15,16], carbon dioxide reduction reaction $\left(\mathrm{CO}_{2} \mathrm{RR}\right)$ [17], but also in organic chemistry.

Considering the preparation of high molecular weight molecules, iron-based complexes are effective, and environmentally-friendly counterparts for copper catalysts in atom transfer radical polymerization (ATRP) techniques-a representative approach of controlled radical polymerization. Due to the disadvantages of commonly used copper catalysts, such as contamination of polymers with stable catalytic complex limiting specialist industrial manufacture, iron-based catalysts attracted attention in this context. Iron-mediated ATRP processes provided a wide range of polymer materials with different architectures and predetermined molecular weight including copolymers, branched architectures (i.e., star and bottlebrush polymers), and organic-inorganic hybrid materials for biomedical use.

Considering the previously published papers in the subject of iron usage in homogeneous and heterogeneous catalysis in organic synthesis [18-21] and controlled radical polymerization techniques [22,23], the presented review demonstrates iron-based catalytically active complexes in a more cross-sectional way. The mechanism and optimization of syntheses catalyzed by iron-based complexes are widely described in the literature, therefore the current development in this field is towards the implementation of iron in more application solutions. Therefore, the review is focused on the use of iron catalysts in the preparation of functional materials, e.g., switchable materials, sustainable and scalable energy storage technologies, drugs in the treatment of cancer, and hybrid polymeric materials.

\section{Applications of Iron-Based Complexes Containing $N$ Donor Ligands in Homogeneous Catalysis}

Iron complexes with $N$ donor ligands are widely used in homogeneous catalysis. Undoubtedly, one of the most important applications of these complexes is the use as catalysts for the oxidation of organic compounds. They can also be applied as switchable materials, components to produce biodegradation materials in medicine and photochemistry, and to imitate artificial photosynthesis. There are also a number of catalytic applications of the iron complexes containing $N$ donor ligands in polymerization and C-C bond formation reactions as well as in reduction, dehydration, hydrocarboxylation, etc. In addition, these compounds may be used as novel noble metal-free photosensitizers. Therefore, besides the oxidation reactions involving this kind of iron complex, representative examples of abovementioned applications in further sections of the chapter will be presented.

\subsection{Functionalization of $\mathrm{C}-\mathrm{H}, \mathrm{C}-\mathrm{C}, \mathrm{C}-\mathrm{N}$ Bond by Iron Complexes with $\mathrm{N}$ Donor Ligands}

From a technological point of view, high selectivity but also targeted and controlled reactivity are required from an effective catalyst. A properly activated catalyst should convert readily available hydrocarbons into valuable products that can be easily separated and purified. Moreover, they generate the least environmentally harmful waste. In this regard, metalloenzymes are still an unrivalled role model to produce new materials. Over 20 years ago a series of iron complexes, functional models of iron oxygen activating enzymes like catechol dioxygenases, methane monooxygenase, or $\alpha$-keto acid-dependent enzymes were synthesized, and have been intensively explored to date [24-27]. Due to the wide range of research conducted on iron complexes with tetra- and pentadentade ligands, 
this paper presents the recently published results. Application of dioxygen or hydrogen peroxide as environmentally friendly oxidants is of great interest in catalytic oxidation systems.

A series of iron catalysts were investigated for the hydroxylation, dihydroxylation and epoxidation of hydrocarbon substrates (Table 1) [28-31]. Paine et al. [31] discussed the influence of the use of tetradentate ligands as supporting ligands. They studied the reactivity of iron(II) benzilate complexes $\left[(L) \mathrm{Fe}^{\mathrm{II}} \text { (benzilate) }\right]^{+}$, while $L=\operatorname{tris}\left(2\right.$-pyridylmethyl)amine (TPMA), $N^{1}, N^{1}$-dimethyl- $N^{2}, N^{2}$-bis(2pyridylmethyl)ethane-1,2-diamine (iso-BPMEN), tris(6-methyl-2-pyridylmethyl)amine (6- $\mathrm{Me}_{3}$-TPMA), $N^{1}, N^{1}$ - dimethyl- $N^{2}, N^{2}$-bis(6-methyl-2-pyridylmethyl)ethane-1,2-diamine (6-Me 2 -iso-BPMEN), $N^{1}, N^{2}$ dimethyl- $N^{1}, N^{2}$-bis(2-pyridylmethyl)ethane-1,2-diamine (BPMEN), tris(2-benzimidazolylmethyl) amine (TBimA), and $N^{1}, N^{2}$-dimethyl- $N^{1}, N^{2}$-bis(6-methyl-2-pyridylmethyl)ethane-1,2-diamine (6- $\mathrm{Me}_{2}$ BPMEN) in the reaction with dioxygen (Figure 1). All of those complexes react with dioxygen to exhibit quantitative decarboxylation of benzylic acid to benzophenone. The combination of $\mathrm{N}$-boc-hydroxylamine in air atmosphere with either (TPMA)Fe ${ }^{\mathrm{II}}$ or (BPMEN)Fe $\mathrm{F}^{\mathrm{II}}$ converts cyclohexene to the allylic hydroxylamine (tert-butyl cyclohex-2-en-1-yl(hydroxy)carbamate) [32]. Additionally, the catalytic reactivity of the iron(II) complex with TPMA [33] or iron(II)-2-aminophenolate complexes with 6-Me $\mathrm{M}_{3}$-TPMA [34] towards oxygenative aromatic $\mathrm{C}-\mathrm{C}$ bond cleavage in catechol [33], 2-aminophenol [33], and 2-aminophenolates [34] were presented. According to recent literature, $\mathrm{N}$-pentadentate ligands-based catalysts also react with molecular oxygen oxidizing cyclohexanone derivatives to $\varepsilon$-caprolactones [35]. It was found that (N4Py)Fe ${ }^{\mathrm{II}}$ is highly selective and efficiently catalyses the Baeyer-Villiger oxidation of cyclohexanone derivatives to $\varepsilon$-caprolactones with molecular oxygen in the presence of various aldehydes such as isobutyraldehyde and benzaldehyde, which may be applied in the production of polymers, pharmaceuticals, and herbicides.

(a)

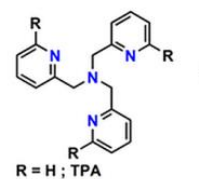

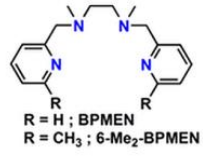

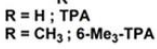

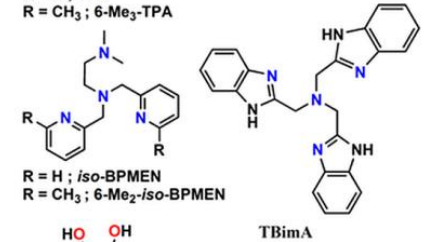
$\mathrm{R}=\mathrm{CH}_{3} ; 6-\mathrm{Me}_{2}$-BPMEN

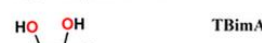

(b)

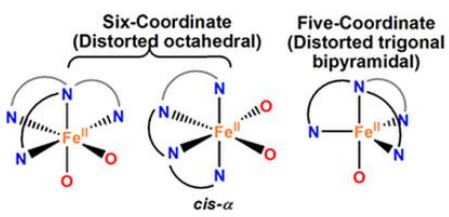

(c)

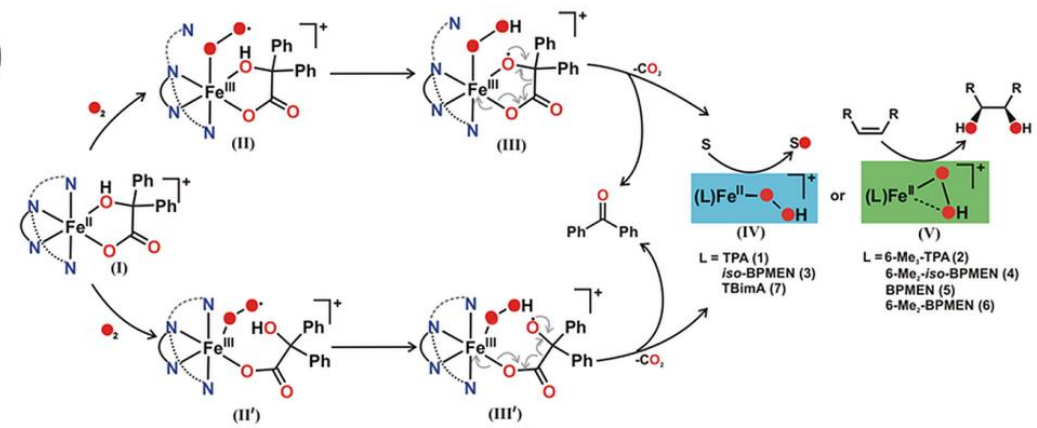

Figure 1. (a) Various types of tetradentate ligand; (b) coordination geometry at the metal center of iron(II) benzilate complexes; (c) The mechanism of oxidative decarboxylation of iron(II) benzilate complexes of tridentate ligands as follows: formation of iron(III) superoxide radical intermediate (II) and analogous iron(III) superoxide radical intermediate (II'), followed by generation of iron(III) hydroperoxo oxyl radical intermediates (III and III') due to hydrogen atom abstraction from the hydroxy group of $\alpha$-hydroxy acid. Decarboxylation of III and III' generates iron(II) hydroperoxo intermediates (IV and V) that could oxidize sulfide to sulfoxide and sulfone, and provide cis-diol product in reactions with olefins (only V) [31]. TPA is equivalent to the TPMA abbreviation. Reprinted with permission from American Chemical Society, Copyright 2016. 
Hydrogen peroxide is another type of "green" oxidizer for organic substrates oxidation with highly stereo- and regioselective bioinspired iron(II) catalysts containing $N$ donor ligands. Initially, it was noticed that a simple (TPMA) $\mathrm{Fe}^{\mathrm{II}}$ complex reacts with $\mathrm{H}_{2} \mathrm{O}_{2}$ to form a powerful, metal-based oxidant for aliphatic C-H bonds oxidation with stereoretention [1]. Recently, mononuclear iron(II) complexes based on a TPMA ligand reacting with $\mathrm{H}_{2} \mathrm{O}_{2}$ found applications in oxidation of cyclohexane [2,36], cyclohexene [5], 1-octene [4,6], cyclooctene [6], 2-heptene [6], adamantane [2], or steroidal substrate (Figure 2c) [4] to the corresponding alcohols and ketones (Figure 2a,b) $[2,6,36]$ or diol and epoxide [4,5]. Iron(II) complexes with tripodal ligand as TPMA and BPMEN were successfully applied to oxyfunctionalize polystyrene (PSt) $[4,37]$. The introduction of polar groups into the backbone of PSt increases its compatibility with polar materials which can facilitate its biodegradation [37]. The same iron(II) complexes were used to oxidize olefin (Jasmone) in the open air system. As observed, the (BPMEN)Fe $\mathrm{Fe}^{\mathrm{II}}$ catalyst mostly gave rise to mixtures of the epoxide and the trans-dihydroxylation products, while the use of the TPMA ligand led to cis-dihydroxylation products [3].

(a)

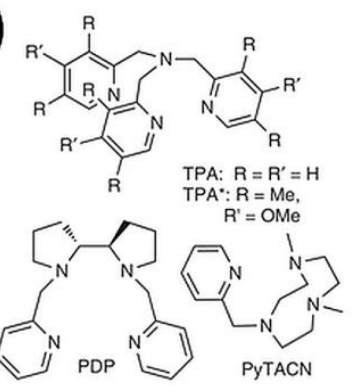

(b)

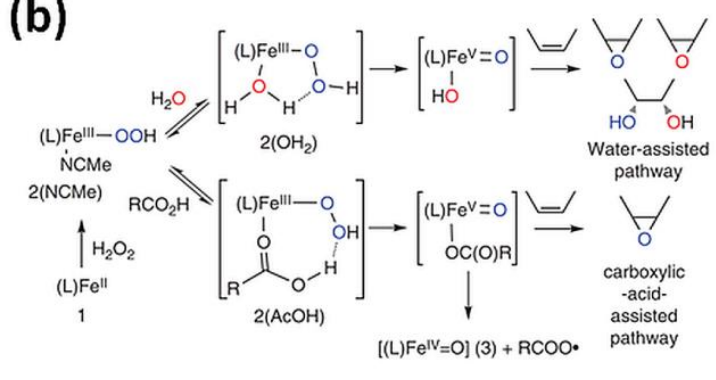

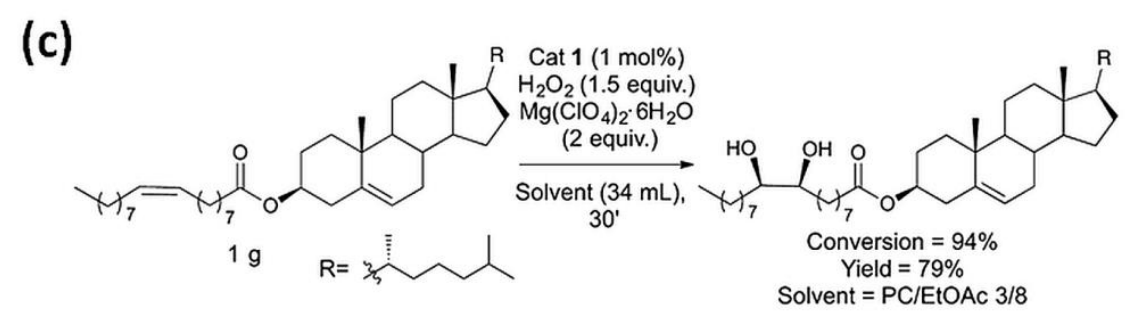

Figure 2. (a) Tetradentate ligands in bio-inspired non-heme iron-mediated olefin oxidations; (b) Activation of $\mathrm{H}_{2} \mathrm{O}_{2}$ by non-heme iron oxidation catalysts with the assistance of water or carboxylic acids with TPMA- $(1-3)$ and TPMA*-based $\left(1^{*}-3 *\right)$ complexes [6]. Reprinted with permission from Nature Publishing Group, a division of Macmillan Publishers Limited, Copyright 2014. (c) Gram-scale syn-dihydroxylation of cholesteryl oleate catalyzed by ${ }^{\text {tips3 }}$ TPMA (1) with $\mathrm{H}_{2} \mathrm{O}_{2}$ as oxidant [4]. Reprinted with permission from American Chemical Society, Copyright 2018.

Goh et al. [7] noticed that epoxides of plant-derived compounds are interesting substrates because of the possibility of incorporating them into various polymers as replacement compounds for traditional petroleum-based starting materials. Therefore, they used (BPMEN)Fe ${ }^{\mathrm{II}}$ catalyst with $\mathrm{H}_{2} \mathrm{O}_{2}$ as the oxidant for the epoxidation of alkenes bearing a carboxylic acid functional group as oleic acid, undecylenic acid, 5-hexenoic acid, and 4-pentenoic acid. The presence of the carboxylic acid functional group led to the formation of epoxide product for oleic and undecylenic and the $\gamma$ - and $\delta$-lactones for 4-pentenoic and 5-hexenoic acid, respectively. 
Table 1. Heterogeneous applications of iron complexes with nitrogen-containing ligands.

\begin{tabular}{|c|c|c|c|c|}
\hline Ligand/Catalyst & Solvent & Type of Reaction & Product & Ref. \\
\hline $\begin{array}{l}\text { TPMA } \\
\text { 6- } \mathrm{Me}_{3} \text {-TPMA } \\
\text { 6- } \mathrm{Me}_{2}-\text {-iso-BPMEN } \\
\text { iso-BPMEN } \\
\text { TBimA } \\
\text { BPMEN, } \\
\text { 6- } \mathrm{Me}_{2} \text {-BPMEN }\end{array}$ & acetonitrile & $\begin{array}{l}\text { decarboxylation of benzylic } \\
\text { acid- } \mathrm{O}_{2} \text { as oxidizer }\end{array}$ & benzophenone & [31] \\
\hline $\begin{array}{l}\text { TPMA } \\
\text { BPMEN } \\
\left(R, R^{\prime}\right)-\text { PDP }\end{array}$ & acetonitrile & $\begin{array}{l}\text { allylic hydroxyamination of } \\
\text { cyclohexene- }-\mathrm{O}_{2} \text { as oxidizer } \\
\text { (C-N bond formation) }\end{array}$ & $\begin{array}{l}\text { tert-butyl cyclohex-2-en- } \\
\text { 1-yl(hydroxy)carbamate }\end{array}$ & [32] \\
\hline TPMA & $\begin{array}{l}\text { acetonitrile-phthalate } \\
\text { buffer }\end{array}$ & $\begin{array}{l}\text { oxygenative regioselective } \\
\mathrm{C}-\mathrm{C} \text { bond cleavage of } \\
\text { catechol and } \\
\text { 2-aminophenol- } \mathrm{O}_{2} \\
\text { as oxidizer }\end{array}$ & $\begin{array}{l}\text { aromatic ring } \\
\text { fission products }\end{array}$ & [33] \\
\hline 6- $\mathrm{Me}_{3}-\mathrm{TPMA}$ & acetonitrile & $\begin{array}{l}\text { selectivity } \mathrm{C}-\mathrm{C} \text { bond } \\
\text { cleavage of substituted } \\
\text { 2-aminophenols- }-\mathrm{O}_{2} \\
\text { as oxidizer }\end{array}$ & $\begin{array}{l}\text { 2-picolinic acid, } \\
\text { 4,6-di-tert-butyl-2H-pyran- } \\
\text { 2-imine, 4,6-di-tert-butyl- } \\
\text { 2-picolinic acid }\end{array}$ & [34] \\
\hline N4Py & acetonitrile & $\begin{array}{l}\text { oxidation of cyclohexanone } \\
\text { derivatives }-\mathrm{O}_{2} \text { as oxidizer }\end{array}$ & $\varepsilon$-caprolactones & [35] \\
\hline $\begin{array}{l}\text { TPMA } \\
\text { BPMEN }\end{array}$ & acetonitrile & $\begin{array}{l}\text { epoxidation, } \\
\text { cis-dihydroxylation, } \\
\text { oxidation of aliphatic C-H } \\
\text { bonds }-\mathrm{H}_{2} \mathrm{O}_{2} \text { as oxidizer }\end{array}$ & oxidized olefins & [1] \\
\hline TPMA & acetonitrile & $\begin{array}{l}\text { oxidation of } \\
\text { cyclohexane- }-\mathrm{H}_{2} \mathrm{O}_{2} \text { and } \\
\text { mCPBA as oxidizer }\end{array}$ & $\begin{array}{l}\text { cyclohexanol, } \\
\text { cyclohexanone }\end{array}$ & [36] \\
\hline $\begin{array}{l}(S, S)-P D P \\
(S, S)-P D P^{*} \\
\text { TPMA } \\
\text { TPMA* }\end{array}$ & acetonitrile & $\begin{array}{l}\text { hydroxylation/oxidation of } \\
\text { cycloalkanes- } \mathrm{H}_{2} \mathrm{O}_{2}, \\
\text { paracetic acid and mCPBA } \\
\text { as oxidizer }\end{array}$ & $\begin{array}{l}\text { cyclohexanol, } \\
\text { cyclohexanone }\end{array}$ & [2] \\
\hline $\begin{array}{l}\text { TPMA* } \\
(S, S)-P D P^{*}\end{array}$ & acetonitrile & $\begin{array}{l}\text { epoxidation of } \\
\text { cycloalkenes- }-\mathrm{H}_{2} \mathrm{O}_{2} \\
\text { as oxidizer }\end{array}$ & $\begin{array}{l}\text { cyclohexene oxide, } \\
\text { 2-cyclohexen-1-one, } \\
\text { 2-cyclohexen-1-ol }\end{array}$ & [5] \\
\hline TPMA* & acetonitrile & $\begin{array}{l}\text { epoxidation of 1-octene, } \\
\text { cyclooctene or } \\
\text { 2-heptene- } \mathrm{H}_{2} \mathrm{O}_{2} \\
\text { as oxidizer }\end{array}$ & $\begin{array}{l}\text { alcohols and ketones } \\
\text { corresponding to the } \\
\text { substrate }\end{array}$ & [6] \\
\hline $\begin{array}{l}\text { tips3 } 3 \text { TPMA } \\
\mathrm{LN}_{4} \mathrm{Me}_{2} \\
\text { Me,MePyTACN }\end{array}$ & $\begin{array}{l}\text { acetonitrile, } \\
\text { acetone, } \\
\gamma \text {-butyrolactone, } \\
\text { ethyl hexanoate, } \\
\text { ethyl acetate, } \\
\text { propylene } \\
\text { carbonate }\end{array}$ & $\begin{array}{l}\text { dihydroxylation/oxidation of } \\
\text { olefins, cholesteryl } \\
\text { oleate- }-\mathrm{H}_{2} \mathrm{O}_{2} \text { as oxidizer }\end{array}$ & $\begin{array}{l}\text { diols and epoxides } \\
\text { corresponding to the } \\
\text { substrate }\end{array}$ & [4] \\
\hline $\begin{array}{l}\text { TPMA } \\
\text { BPMEN }\end{array}$ & dichloromethane & $\begin{array}{l}\text { oxyfunctionalization of } \\
\text { polystyrene- }-\mathrm{H}_{2} \mathrm{O}_{2} \\
\text { as oxidizer }\end{array}$ & $\begin{array}{l}\text { polymer product with keto } \\
\text { and hydroxyl groups }\end{array}$ & [37] \\
\hline $\begin{array}{l}\text { TPMA } \\
\text { BPMEN }\end{array}$ & acetonitrile & $\begin{array}{l}\text { cis-dihydroxylation } \\
\text { of alkenes- } \mathrm{H}_{2} \mathrm{O}_{2} \\
\text { as oxidizer }\end{array}$ & $\begin{array}{l}\text { epoxide and the } \\
\text { trans-dihydroxylation, } \\
\text { cis-dihydroxylation } \\
\text { products, cis-diols }\end{array}$ & [3] \\
\hline
\end{tabular}


Table 1. Cont

\begin{tabular}{|c|c|c|c|c|}
\hline Ligand/Catalyst & Solvent & Type of Reaction & Product & Ref. \\
\hline BPMEN & acetonitrile & $\begin{array}{l}\text { epoxidation of alkenes } \\
\text { bearing a carboxylic acid } \\
\text { functional } \\
\text { groups- } \mathrm{H}_{2} \mathrm{O}_{2} \text { as oxidizer }\end{array}$ & epoxides, lactones & [7] \\
\hline $\begin{array}{l}\text { TPMA } \\
\text { BPyA }\end{array}$ & water & $\begin{array}{l}\text { water oxidation-sodium } \\
\text { periodate as oxidizer }\end{array}$ & $\mathrm{O}_{2}, \mathrm{H}_{2}$ & [38] \\
\hline $\begin{array}{l}\text { TPMA } \\
\mathrm{Me}_{3} \mathrm{TACN} \\
\mathrm{LN}_{4} \mathrm{Me}_{2}\end{array}$ & water & $\begin{array}{l}\text { water oxidation-cerium(IV) } \\
\text { ammonium nitrate } \\
\text { as oxidizer }\end{array}$ & $\mathrm{O}_{2}, \mathrm{H}_{2}$ & [39] \\
\hline PyTACN & water & $\begin{array}{l}\text { water oxidation-cerium(IV) } \\
\text { ammonium nitrate } \\
\text { as oxidizer }\end{array}$ & $\mathrm{O}_{2}, \mathrm{H}_{2}$ & [40] \\
\hline N4Py & water/acetonitrile & $\begin{array}{l}\text { photodriven water } \\
\text { oxidation-plastoquinone } \\
\text { as oxidazer }\end{array}$ & $\mathrm{O}_{2}, \mathrm{H}_{2}$ & [41] \\
\hline TPMA & $\begin{array}{l}\text { methanol, ethanol, } \\
\text { acetonitrile, } \\
\text { dichloromethane }\end{array}$ & - & spin-crossover compounds & [42] \\
\hline TPMA & methanol, water & - & spin-crossover compounds & [43] \\
\hline $\begin{array}{l}\text { acetylacetonato } \\
\text { ligand }^{\text {(a) }}\end{array}$ & acetonitrile & redox processes & $\begin{array}{l}\text { p-type dye-sensitized } \\
\text { solar cells }\end{array}$ & [44] \\
\hline $\begin{array}{l}\text { PyTACN } \\
\mathrm{H}_{2} \text { pmen }\end{array}$ & $\begin{array}{l}\text { acetonitrile/ionic } \\
\text { liquid }\end{array}$ & redox processes & redox flow batteries & [45] \\
\hline TPMA & $\begin{array}{l}\text { DMSO/water } \\
\text { DMSO/Dulbecco's } \\
\text { modified } \\
\text { eagle's medium }\end{array}$ & redox processes & $\begin{array}{l}\text { drug with } \\
\text { anti-proliferative and } \\
\text { anti-inflammatory } \\
\text { activities }\end{array}$ & [46] \\
\hline N4Py & DMSO/water & $\begin{array}{l}\text { oxidative } \\
\text { DNA cleavage }\end{array}$ & drug antitumor activity & [47] \\
\hline $\begin{array}{l}\mathrm{BPBP} \\
6-\mathrm{Me}_{2}-\mathrm{BPBP} \\
\mathrm{BPMCN} \\
\mathrm{Me}_{2} \mathrm{PyTACN} \\
\mathrm{MePy}_{2} \mathrm{TACN}\end{array}$ & water & $\begin{array}{l}\text { oxidative } \\
\text { DNA cleavage }\end{array}$ & drug antitumor activity & [48] \\
\hline $\begin{array}{l}\left(S, S^{\prime}\right)-\mathrm{BPBP} \\
\mathrm{Me}_{2} \text { PyTACN }\end{array}$ & water & $\begin{array}{l}\text { oxidative } \\
\text { DNA cleavage }\end{array}$ & $\begin{array}{l}\text { peptide conjugates with } \\
\text { antitumor activity }\end{array}$ & [49] \\
\hline $\mathrm{NCCN}$ & acetonitrile & $\begin{array}{l}\text { epoxidation of olefins - } \\
\mathrm{H}_{2} \mathrm{O}_{2} \text {, tert-butyl } \\
\text { hydroperoxide and urea } \\
\text { hydrogen peroxide } \\
\text { adduct as oxidizer }\end{array}$ & epoxides & [8] \\
\hline $\mathrm{NCCN}$ & acetonitrile & $\begin{array}{l}\text { hydroxylation of benzene } \\
\text { and toluene- } \mathrm{H}_{2} \mathrm{O}_{2} \\
\text { as oxidizer }\end{array}$ & $\begin{array}{l}\text { phenol, cresols }(o-, m- \\
\text { and } p-)\end{array}$ & [50] \\
\hline $\begin{array}{l}\text { NCCN } \\
\text { analogous-bis( } N \text { - } \\
\text { heterocyclic carbene)- } \\
\text { bis(pyridine), } \\
\text { tetra( } N \text {-heterocyclic } \\
\text { carbene) }\end{array}$ & acetonitrile & olefination of aldehyde & E-ethyl cinnamate & [51] \\
\hline
\end{tabular}


Table 1. Cont.

\begin{tabular}{|c|c|c|c|c|}
\hline Ligand/Catalyst & Solvent & Type of Reaction & Product & Ref. \\
\hline $\begin{array}{l}\text { 3-methyl-1-(pyridin- } \\
\text { 2-ylmethyl)- } \\
\text { benzimidazol-2-ylidene } \\
\text { 3-benzyl-1-(pyridin- } \\
\text { 2-ylmethyl)-benzimidazol- } \\
\text { 2-ylidene } \\
\text { 3-(4-tert-butyl-benzyl)-1- } \\
\text { (pyridin-2-ylmethyl)- } \\
\text { benzimidazol-2-ylidene } \\
\text { 1,3-di-(2-ethylenepyridyl } \\
\text { methyl)-benzimidazol- } \\
\text { 2-ylidene }\end{array}$ & isopropanol & $\begin{array}{l}\text { transfer hydrogenation of } \\
\text { aldehydes, ketones }\end{array}$ & alcohols & {$[52]$} \\
\hline $\begin{array}{l}\text { enolate chelating } \\
N \text {-heterocyclic carbenes }\end{array}$ & toluene & $\begin{array}{l}\text { ring-opening polymerization } \\
\text { of } \varepsilon \text {-caprolactone }\end{array}$ & polycaprolactone & {$[53,54]$} \\
\hline $\begin{array}{l}\text { bis(amidinato)-N- } \\
\text { heterocyclic carbene } \\
\text { ancillary ligand }\end{array}$ & 1,2-dimethoxyethane & $\begin{array}{l}\text { polymerization of } \\
(\mathrm{rac}) \text {-lactide }\end{array}$ & poly(lactic acid) & [55] \\
\hline $\mathrm{CNC}$ & acetonitrile/water & water reduction & $\mathrm{H}_{2}$ & {$[56]$} \\
\hline $\begin{array}{l}N \text {-heterocyclic carbene } \\
\text { with strong } \\
\text { electron-donating } \\
\text { substituents }\end{array}$ & acetonitrile & redox processes & $\begin{array}{l}\text { iron-based dye } \\
\text { sensitized solar cells }\end{array}$ & [57] \\
\hline $\begin{array}{l}N \text {-heterocyclic carbene } \\
\text { ligands }\end{array}$ & water/DMSO & - & $\begin{array}{l}\text { iron complexes with } \\
\text { antibacterial activities }\end{array}$ & {$[58]$} \\
\hline $\begin{array}{l}\text { C-functionalized } \\
\text { neutral and anionic } \\
\text { tris(pyrazolyl)methanes }\end{array}$ & acetonitrile/water & $\begin{array}{l}\text { hydrocarboxylation of } \\
\text { cyclohexane }\end{array}$ & cyclohexanecarboxylic acid & [59] \\
\hline tris(pyrazolyl)methanes & - & $\begin{array}{l}\text { oxidation of cyclohexane } \\
\text { with ozone }\end{array}$ & adipic acid & {$[60]$} \\
\hline tris(pyrazolyl)methanes & - & $\mathrm{CO}_{2}$ hydrogenation with $\mathrm{H}_{2}$ & methanol & [61] \\
\hline tris(pyrazolyl)methanes & acetonitrile & $\begin{array}{l}\text { oxidation of } o-, m \text { - or } \\
p \text {-xylene }-\mathrm{H}_{2} \mathrm{O}_{2} \text { as oxidizer }\end{array}$ & $\begin{array}{l}\text { corresponding } \\
\text { methylbenzyl alcohols, } \\
\text { tolualdehydes and } \\
\text { toluic acids }\end{array}$ & [62] \\
\hline tris(pyrazolyl)methanes & $\begin{array}{l}\text { acetonitrile, } \mathrm{IL}, \\
\mathrm{sCO}_{2} \\
\mathrm{IL} / \mathrm{sCO}_{2}\end{array}$ & $\begin{array}{l}\text { oxidation of } \\
\text { cyclohexane-tert-butyl } \\
\text { hydroperoxide as oxidizer }\end{array}$ & $\begin{array}{l}\text { cyclohexanol, } \\
\text { cyclohexanone }\end{array}$ & [63] \\
\hline
\end{tabular}

Oxidation of two water molecules to form dioxygen is an attractive reaction enabling the implementation of processes imitating artificial photosynthesis. This reaction can be used to produce solar fuels. Carrying out this process in laboratory conditions requires catalysts that can mediate $\mathrm{O}-\mathrm{O}$ bond formation. Recently, iron(II) with TPMA [38,39] and 1-(2'-pyridylmethyl)-4,7-dimethyl-1,4,7triazacyclononane (PyTACN) [40] complexes were considered as water oxidation catalysts. It was proved that the introduction of an internal base in the coordination sphere of the iron complex reduces the energy of the $\mathrm{O}-\mathrm{O}$ bond formation barrier. It has a clear impact on the future design of iron(II) $\mathrm{N}$-dentate catalyst for water oxidation [40]. Also, $\mathrm{N}$-pentadentate catalysts such as (N4Py)Fe ${ }^{\mathrm{II}}$ have been successfully applied in photodriven water oxidation reaction, using $p$-benzoquinone derivatives as plastoquinone analogues [41].

\subsection{Application Complexes Containing N Donor Ligands as Switchable Material, Sensitizer}

Iron(II) TPMA complexes are an example of switchable material, also named spin-crossover complexes, that could potentially be used in the fields of information storage and display 
technology. A spin-switching phenomenon occurs for $3 d^{4}-3 d^{7}$ transition metals. Spin states of Fe(TPMA) complexes can be finely tuned between the high- and the low-spin state of the metal centres. Tao et al. [42] found that the encapsulation of different solvents in a crystal lattice can effectively tune the structural packing modes. External stimuli (light, temperature, pressure) regulate the colour, magnetic properties and electrical conductivity of these compounds, which makes them promising materials for storing high-density information, sensors, switches or spintronics. Reactions of TPMA ligand and $\mathrm{Fe}\left(\mathrm{ClO}_{4}\right)_{2} \cdot 6 \mathrm{H}_{2} \mathrm{O}$ in the presence tricyanometallate precursors ( $\mathrm{Tp}^{4-\mathrm{Me}}$-tri(4-methyl-pyrazol-1-yl)borate), $\left(\mathrm{Ph}_{3} \mathrm{PMe}\right)\left[\left(\mathrm{Tp}^{4-\mathrm{Me}}\right) \mathrm{Fe}(\mathrm{CN})_{3} \cdot 0.5 \mathrm{CH}_{3} \mathrm{CN}\right]$ and MeTp-methyltris(pyrazolyl)borate, $\left.\left(\mathrm{NBu}_{4}\right)\left[(\mathrm{MeTp}) \mathrm{Fe}(\mathrm{CN})_{3}\right]\right)$ provided two new cyanido-bridged mixed-valence $\left(\mathrm{Fe}^{\mathrm{III}}{ }_{2} \mathrm{Fe}^{\mathrm{II}}{ }_{2}\right.$ ) molecular squares with high thermal stability, thermally-induced single spin transition ( $\mathrm{Fe}^{\mathrm{II}}{ }_{\mathrm{LS} 2} / \mathrm{Fe}^{\mathrm{III}}{ }_{\mathrm{LS} 2} \leftrightarrow \mathrm{Fe}^{\mathrm{II}}{ }_{\mathrm{HS} 2} / \mathrm{Fe}^{\mathrm{III}}{ }_{\mathrm{LS} 2}$ ) behaviour and reversible single-crystal to single-crystal (SC-SC) transformations induced by guest desorption and re-sorption or solvent exchange, useful in the development of new multistable materials like magnetic sensors and molecular switches [43].

Suitably modified TPMA ligands are also used as a sensitizer, achieving high efficiency of energy conversion and low production cost in dye-sensitized solar cells. Iron complexes, as a redox mediator, were applied in p-type dye-sensitized solar cells in conjunction with the PMI-6T-TPMA (perylene-thiophene-triphenylamine) sensitizer [44]. More recently, iron(II) complexes with a PyTACN ligand, capable of stabilizing both high and low oxidation states of metal centres for redox flow batteries, were successfully studied. Redox flow batteries are a promising technology for scalable energy storage. They proposed a design principle for charge carriers that could be used in redox flow batteries based on combining PyTACN ligands that could promote multiple redox events and high open circuit voltage values [45].

\subsection{Complexes with N Donor Ligands as Materials in the Effective Treatment of Cancer}

Antiproliferative activity of TPMA was successfully combined with anti-inflammatory characteristics of diclofenac, forming [(TPMA)Fe $\mathrm{Fe}^{\mathrm{II}}$ (diclofenac) ${ }^{+}$complex. The iron(II) complex exhibited an anti-proliferative effect on a human breast cancer cells line (MDA-MB-231), which provides useful insight into the development of non-platinum anti-cancer drugs with anti-inflammatory effects [46]. Also, $N$-pentadentate iron(II) complexes of N4Py are excellent synthetic mimics of bleomycin-natural antibiotics used clinically to induce antitumor activity. In the presence of cellular metal ions and oxygen, those catalysts are capable of mediating oxidative DNA cleavage, which is believed to be the major contributor to their antitumor activity. Treatment of SKOV-3 and MDA-MB-231 cancer cells with N4Py-based mimics iron(II) complexes gave rise to double-strand DNA breaks as efficient as with the use of bleomycin. The results indicate that the designed synthetic bioinorganic model complexes were as active as the parent natural products [47]. Peptide-mediated drug delivery constitutes another versatile tool for releasing therapeutic agents into cancer cells. One of the most common approaches to facilitate the cellular uptake of anticancer drugs is based on their conjugation to a cell-penetrating peptide. Various iron-based ligands were demonstrated to chelate intracellular iron in cancer cells. The resulting redox-active moieties promote apoptosis via iron-dependent pro-oxidant mechanisms. The anti-cancer activity of amine-pyridine-based iron complexes relies on different inter-dependent processes, involving intracellular Fe(II) chelation, generation of reactive oxygen species, DNA fragmentation through oxidative mechanisms, induction of cell cycle arrest, and apoptosis [48]. Moreover, iron complexes with a nitrogen-rich tetradentate ligand $\left(\mathrm{Me}_{2} \mathrm{PyTACN}\right)$ form powerful oxidation species upon reaction with peroxides. The conjugation of a 1,4-dimethyl-7-(2-pyridylmethyl)-1,4,7-triazacyclononane ( $\mathrm{Me}_{2}$ PyTACN) ligand to a cell-penetrating peptide CPP, such as BP16, was envisaged. The results initiate synthesis of novel peptide conjugates for pro-oxidant anticancer therapies. Proposed peptide conjugates incorporate the $N$-based ligands at the $\mathrm{N}$-terminus of the cell-penetrating peptide BP16. Analysis of the cytotoxicity of the peptide conjugates showed that the position of the ligand influenced the IC50 values and the incorporation of the $\beta$ Ala-Lys dipeptide rendered non-active sequences [49]. 
Besides the catalysts containing $N$ donor ligands discussed above, undoubtedly crucial for homogeneous iron catalysis are iron $\mathrm{N}$-heterocyclic carbene complexes (iron NHC complexes) and C-scorpionate iron(II) complexes, that will be presented below. The most important uses of the above-described iron compounds in catalysis focused on various oxidation processes, whereas the major applications of the iron NHC and C-scorpionate complexes, alongside oxidation reactions, e.g., polymerization, $\mathrm{C}-\mathrm{C}$ bond formation, hydrogenation and hydrocarboxylation reactions, are included as well.

\subsection{Iron N-Heterocyclic Carbene Complexes}

Grubbs and Louie reported the first example of iron NHC complexes successfully used as catalysts [64]. In their work iron(II) halides bearing imidazolylidene ligands were applied as catalysts for the atom transfer radical polymerization (ATRP) of styrene and methyl methacrylate. Products of the homogeneous polymerizations-PSt and poly(methyl methacrylate) (PMMA) are among the most important and widely used polymers with numerous applications.

Organometallic compounds as $\mathrm{N}$-heterocyclic carbene-ligated iron complexes are highly resistant toward decomposition due to strong $\sigma$-electron donating properties of NHC ligands that usually form tough bonds with most metal centres. Among accessibility and steric and electronic tunability, chemical stability is one of the most important features of iron NHCs. Owing to their catalytic properties, these complexes found widespread use in many important reactions, e.g., C-C bond formation (including Kumada and Suzuki cross-coupling reactions [65,66], and allylic alkylation [65]), C-X, C-B [65,66] and C-N [65-68] bond formation, oxidation [65-68] and epoxidation [68] reactions, reduction [65-68], dehydration [67], cyclization [65] and polymerization reactions [65,66]. Applicability of iron NHC complexes in homogeneous catalysis has been frequently successfully demonstrated and this class of compounds might find applications in industrial chemistry and pharmaceutical syntheses [65-68].

Kühn et al. [8] applied the iron(II) NHC complex bearing a tetradentate di(o-imidazol-2ylidenepyridine)methane (NCCN) ligand, stable in air and water, as catalysts for the epoxidation of olefins with $\mathrm{H}_{2} \mathrm{O}_{2}$, resulting in high yields and selectivity (Figure 3a). Epoxides are a significant group of industrial chemicals commonly used as intermediates in various technological processes. Hydroxylation of benzene catalyzed by iron(II) complex with NCCN ligand in mild temperature with the use of aqueous $\mathrm{H}_{2} \mathrm{O}_{2}$ [50] afforded high selectivity for phenol. Hydroxylation of toluene in analogous reaction [50] brought cresols $(o-, m-$ and $p$-) as the main products with high selectivity for ring hydroxylation. The selective direct oxidation of aromatics compounds is currently one of the most challenging process in organic chemistry, therefore abovementioned reactions might be particularly relevant in this regard.

The iron(II) NCCN complexes are able to catalyze olefinic C-C bond generation in a Wittig reaction, as has been shown in recent work [51]. A one-pot reaction protocol for aldehyde olefination with high olefin yields with very good $E$-selectivity with the use of iron(II) complex with NCCN analogous was presented.. The Wittig reaction is one of the important C-C bond formation processes and is widely used in organic synthesis for the development of alkenes. 
(a)
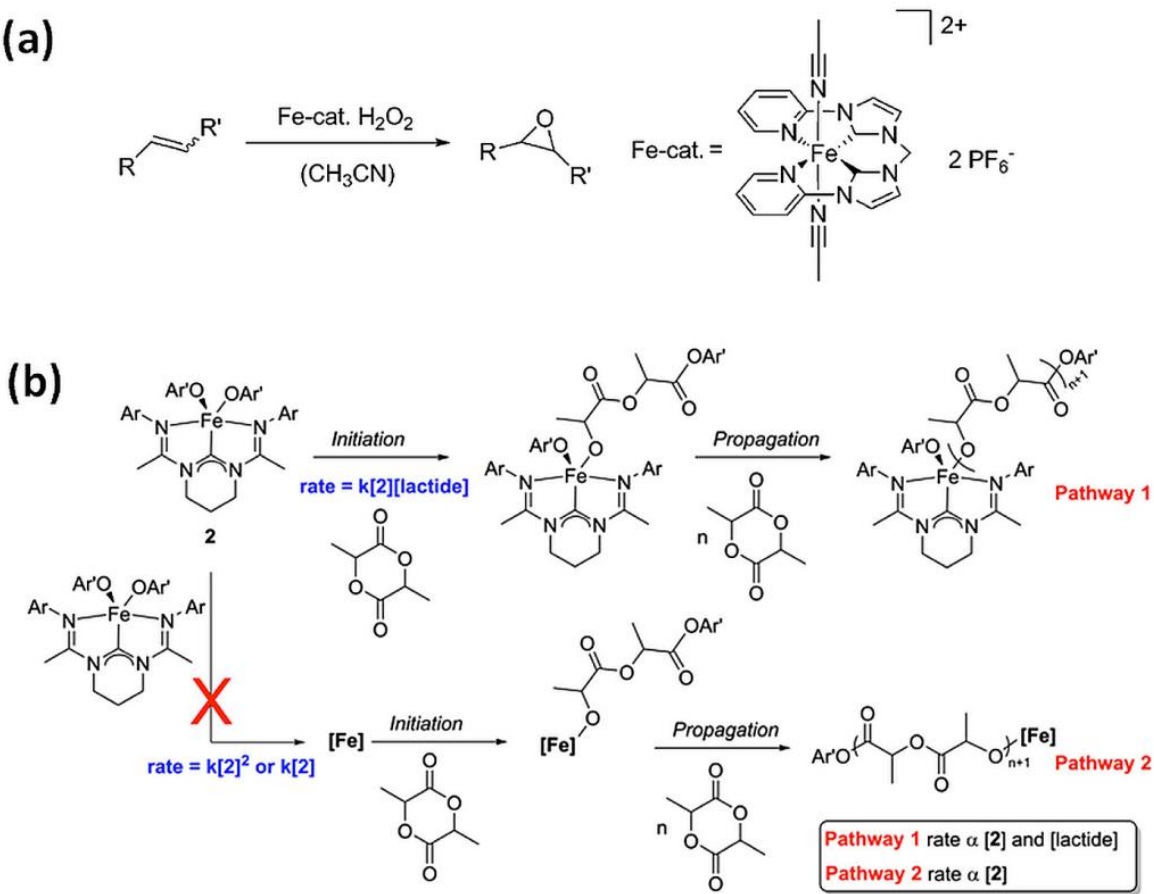

Figure 3. (a) Catalytic epoxidation of olefins using $N$-heterocyclic carbene complex (NCCN) and $\mathrm{H}_{2} \mathrm{O}_{2}$ as the oxidant [8]. Reprinted with permission from WILEY-VCH Verlag GmbH \& Co. KGaA, Copyright 2014. (b) N-heterocyclic carbene complex-(carbenodiamidine)Fe(4-methoxyphenoxide) 2 (2) in polymerization of lactide [55]. Reprinted with permission from Elsevier Ltd., Copyright 2014.

Piano-stool iron(II) NHC complexes, besides the $N$-heterocyclic carbene motif, bear cyclopentadienyl (Cp) ligands [65,67]. An efficient catalyst for transfer hydrogenation of carbonyl compounds, namely piano-stool iron(II) complex $[\mathrm{Fe}(\mathrm{L}) \mathrm{Cp}(\mathrm{CO})] \mathrm{X}, \mathrm{L}=$ substituted derivatives of 1-(pyridin-2-ylmethyl)-benzimidazol-2-ylidene group, was synthesized [52]. Hydrogenation of carbonyl substrates bringing hydroxyl compounds including aldehydes conversion into corresponding alcohols is a notable transformation in chemical technology.

Ring-opening polymerization of $\varepsilon$-caprolactone catalyzed by aryloxo-functionalized NHC complexes of iron(II) was effectively conducted $[53,54]$. The complexes were subsequently modified to achieve better stability and higher catalytic activity. The product, polycaprolactone, is a biodegradable polyester often used as an additive for resins improving their impact resistance and biodegradability or as a plasticizer to polyvinyl chloride. Polycaprolactone also showed biomedical and other applications, e.g., in part fabrication or rapid prototyping.

Novel iron bis(alkoxide) complex bearing bis(amidinato)- $N$-heterocyclic carbene ancillary ligand, (carbenodiamidine)Fe(4-methoxy-phenoxide) ${ }_{2}$ was successfully applied as a catalyst for controlled polymerization of (rac)-lactide [55]. The substrate of the reaction, ( $\mathrm{rac}$ )-lactide is derived from renewable resources (e.g., sugar cane, corn starch). The product, poly(lactic acid) (PLA), is a completely biodegradable polymer used for the production of packaging materials, textiles and is applied in the biomedical industry, making this area of research highly attractive.

Iron compounds as naturally abundant and low cost materials are increasingly considered as photocatalysts and photosensitizers in photochemistry as alternatives of photofunctional complexes based on rare or heavy metals. Light-driven applications of iron NHC complexes have been recently a subject of much research [69]. Bauer et al. [56] developed a new synthesis protocol for heteroleptic terpy-NHC iron(II) complexes and presented these novel Fe(II)-NHC compounds as noble metal-free photosensitizers (PS) for light-driven water reduction. Photocatalytic water reduction as a clean and sustainable source of hydrogen provides green energy and, in addition, employing for hydrogen production another green energy source of unlimited 
abundancy-the sunlight. The observed activity of complexes $\left[(\mathrm{CNC}) \mathrm{Fe}-\eta^{3}\right.$-terpy $] \mathrm{X}_{2}, \mathrm{CNC}=$ 2,6-bis-[3-(2,6-diisopropylphenyl)-imidazol-2-ylidene]pyridine, $\mathrm{X}=\mathrm{PF}_{6}{ }^{-}$or $\mathrm{BPh}_{4}{ }^{-}$, compared to the activity of established iridium PS $\left[\operatorname{Ir}(\mathrm{ppy})_{2} \mathrm{bpy}_{[}\left[\mathrm{PF}_{6}\right]\right.$, proved the potential for new $\mathrm{Fe}(\mathrm{II})-\mathrm{NHC}$ complexes for photocatalytic water reduction. Novel iron(II) NHC dye sensitizers were synthesized and tested in working solar cells [57]. The development of efficient iron-based dye sensitized solar cells (DSSCs) is a great challenge for photovoltaics. This work presents characterization of iron(II) NHC sensitized photoelectrodes in working DSSCs, and the results may be the basis for developing efficient iron-based dyes for photoelectrochemical applications. Exploiting solar energy for effective electricity production and storage constitutes one of the most important technological tasks.

Iron NHCs widely used in catalysis and photochemical applications have recently found potential medicinal implementations. A group of iron(II) NHC complexes has been developed using a microwave-assisted route and evaluated over antibacterial activity [58]. The results, obtained for tests with standard bacterial strains (Staphylococcus aureus and Escherichia coli), gave some perspectives for the development of new compounds having antibacterial properties and opening the way for devising a new class of antibiotics.

\subsection{C-Scorpionate Iron(II) Complexes}

Scorpionate ligands, i.e., poly(azolyl)borates and poly(azolyl)alkanes are a suitable and versatile class of ligands due to the type and number of azolyl groups, moreover, the substituents on these groups or on the $\mathrm{B}$ or $\mathrm{C}$ centres are flexible and can be readily modified to receive ligands with various steric and electronic profiles [70]. In this consideration, these compounds found applications in several areas of research including homogeneous catalysis, organic synthesis, prospective advanced materials, and modelling of active sites of metalloenzymes [71].

The use of metallic complexes with scorpionate ligands as catalysts expanded a range of developments. For instance, homoscorpionate tris(pyrazol-1-yl)methane metal complexes were used as catalysts in the oxidative functionalization of alkanes, alkenes, and ketones under mild conditions in homogeneous catalytic systems [72]. Most recent works show that transition metal complexes of C-homoscorpionate tris(pyrazol-1-yl)methanes were employed as catalysts for an increasing number of challenging and industrially significant reactions, e.g., selective oxidation of alkanes and alcohols, hydrocarboxylation of $C_{n}$ alkanes into $C_{n+1}$ carboxylic acids, and carbon dioxide hydrogenation to methanol. Heck, Sonogashira Henry C-C coupling reactions and azide-alkyne Huisgen cycloaddition have been also reported [73].

C-Scorpionate iron(II) complexes [ $\left.\mathrm{FeCl}_{2}\left\{\mathrm{k}^{3}-\mathrm{HC}(\mathrm{pz})_{3}\right\}\right]$ (pz $=$ pyrazol-1-yl), $\mathrm{Li}\left[\mathrm{FeCl}_{2}\left\{\mathrm{k}^{3}-\mathrm{SO}_{3} \mathrm{C}(\mathrm{pz})_{3}\right\}\right]$ and $\left[\mathrm{FeCl}_{2}\left\{\mathrm{k}^{3}-\mathrm{HOCH}_{2} \mathrm{C}(\mathrm{pz})_{3}\right\}\right]$ received straightway from iron(II) chloride and appropriate scorpionate ligands in ethanol or water were applied as catalysts for hydrocarboxylation of cyclohexane to cyclohexanecarboxylic acid in aqueous/acetonitrile medium at a mild temperature, receiving very good yields (up to 69\%) and high selectivity (up to 98\%) [59]. Cyclohexane was a model substrate of the reaction due to the particular significance of cyclohexanecarboxylic acid, used in industry as a flavouring agent; a stabilizer for rubber; and as an additive for paints, varnishes, soaps, and lubricating oils.

A highly catalytic active bio-inspired C-scorpionate iron(II) complex was developed, focusing on developing more sustainable, alternative catalytic systems for crucial industrial processes [60-63]. The presented iron(II) complex catalyzed synthesis of adipic acid directly from cyclohexane via single-pot oxidation with ozone as an oxidizing agent and pyrazine carboxylic acid as a promoter of the reaction [60]. Adipic acid, owing to its versatility as a building block, is a highly valuable chemical, produced on a large scale worldwide and used as a monomer for nylon- 6,6 synthesis and also to produce polyurethane foams and resins, polyesters, lubricants, and adhesives. Environmentally benign, solvent- or amine-free synthesis of methanol (one of the most important building block in the chemical industry) was achieved via single-pot hydrogenation of carbon dioxide catalyzed by $\left[\mathrm{FeCl}_{2}\left\{\mathrm{k}^{3}-\mathrm{HC}(\mathrm{pz})_{3}\right\}\right]$ complex at a mild temperature [61]. This highly efficient reaction brought turnover numbers up to 2300 with $44 \%$ yield. Fast conversion of xylenes $(o-, m$ - and $p$-) to the corresponding 
methylbenzyl alcohols, tolualdehydes, and toluic acids was attained in the reaction catalyzed by $\left[\mathrm{FeCl}_{2}\left\{\mathrm{~K}^{3}-\mathrm{HC}(\mathrm{pz})_{3}\right\}\right]$ complex under mild conditions $\left(35^{\circ} \mathrm{C}\right.$, low catalysts loading) and with green oxidant ( $30 \%$ aqueous $\mathrm{H}_{2} \mathrm{O}_{2}$ ) in the presence of the co-catalyst (nitric acid) [62]. The iron(II) complex $\left[\mathrm{FeCl}_{2}\left\{\mathrm{k}^{3}-\mathrm{HC}(\mathrm{pz})_{3}\right\}\right]$ and its alcohol derivative $\left[\mathrm{FeCl}_{2}\left\{\mathrm{k}^{3}-\mathrm{HOCH}_{2} \mathrm{C}(\mathrm{pz})_{3}\right\}\right]$ complex were successfully applied as catalysts for cyclohexane oxidation to cyclohexanol and cyclohexanone with tert-butyl hydroperoxide in ionic liquids (IL), supercritical carbon dioxide $\left(\mathrm{scCO}_{2}\right)$, and mixtures of these solvents $\left(\mathrm{scCO}_{2}\right.$-IL) [63]. The reactions provided remarkable yields of the products, the finest in mixed solvents $\left(\mathrm{scCO}_{2}\right.$-IL) media.

As presented, iron as a non-noble metal catalyst in the context of homogeneous catalysis can be considered as a versatile tool in chemical technologies and global production. It was successfully applied in a wide range of type of the reaction, including oxidation processes of low molecular weight molecules giving substrates for industrial-scale production; redox flow batteries or solar cells application; and also biological macromolecules as DNA providing anti-proliferative, anti-inflammatory, and anti-tumour drugs. It is worth noticing that iron complexes with $N$ donor ligands also can be used as homogeneous catalysts of $\mathrm{H}_{2}$ evolution and $\mathrm{CO}_{2}$ reduction catalysts that use $\mathrm{H}_{2} \mathrm{O}$ as a proton source, co-solvent, or reaction medium. Those processes are important transformations in the synthesis of renewable fuels from abundant water or the greenhouse gas $\mathrm{CO}_{2}$ is a major step toward creating sustainable and scalable energy storage technologies [74]. Iron-based catalysts were also applied in heterogeneous catalysis, expanding the field of their potential applications.

\section{Heterogeneous Applications of Iron Complexes with Nitrogen-Containing Ligands}

The previous considerations of the review were limited to homogeneous catalysts. This type of catalyst is usually characterized by high selectivity and versatility but is also susceptible to aggressive chemical agents, high temperature and problems related to separation from the reaction system. In contrast, heterogeneous catalysts (traditionally based on metals, metal oxides or zeolites) offer high thermal stability and easiness of separation, nevertheless, they are less selective then homogeneous ones. There is a hope that the route for the preservation of the best features inherent in these somewhat opposite approaches leads in the middle of them-through surface immobilization of molecular catalysts.

Since Haag and Whitehurst published their seminal paper half a century ago, reporting the first catalyst based on supported metal complexes [75], there was substantial work made to prepare the materials by anchoring homogeneous catalysts on various solid substrates. Shrinking natural resources and environmental pollution create an urgent need for rapid development of electrochemical energy converting devices, including batteries, fuel cells and water splitting systems. Traditional (and still the best) catalysts are based on precious group metals (PGMs), mainly platinum. However, $\mathrm{Pt}$ is scarce and very expensive. The most promising group of PGM-free electrocatalysts are metal-nitrogen-carbon (Me-N-C) materials, frequently heat-treated. Iron-based ones stand out, owing to good activity and low cost. It was shown in 1964 by Jasinski [9] that some metals together with nitrogen macrocyclic compound (phthalocyanines), attached to the electrode can effectively electrocatalyse oxygen reduction reaction (ORR). At the moment $\mathrm{Fe}$ complexes with $\mathrm{N}$-containing ligands are exploited for the synthesis of electrocatalysts investigated for ORR, OER, HER, and $\mathrm{CO}_{2} \mathrm{RR}$, but also in organic chemistry (Table 2). The catalysts can by non-treated thermally or subjected to thermal treatment (most frequently pyrolysis). 
Table 2. A summary of iron complexes with nitrogen-containing ligands applied in homogeneous catalysis.

\begin{tabular}{|c|c|c|c|c|c|c|}
\hline Ligand/Catalyst & $\begin{array}{l}\text { Type of Solid } \\
\text { Substrate }\end{array}$ & $\begin{array}{l}\text { Type of } \\
\text { Attachment }\end{array}$ & Solvent & $\begin{array}{l}\text { Type of } \\
\text { Reaction }\end{array}$ & Product & Ref. \\
\hline $\begin{array}{l}\text { 5,10,15-tris(2,6- } \\
\text { hydroxyphenyl)-20- } \\
\text { (3-(pyren-1- } \\
\text { yl)propyl)porphyrin }\end{array}$ & $\begin{array}{l}\text { CNTs, glassy } \\
\text { carbon electrode }\end{array}$ & $\begin{array}{l}\text { non-covalent } \\
\text { bonds }\end{array}$ & water & $\begin{array}{l}\mathrm{CO}_{2} \text { to } \mathrm{CO} \\
\text { conversion }\end{array}$ & $\begin{array}{l}\text { highly active catalytic } \\
\text { carbon } \\
\text { based materials }\end{array}$ & [76] \\
\hline bpy & $\begin{array}{l}\text { nonporous graphitic } \\
\text { carbon } \\
\text { nitride support }\end{array}$ & $\begin{array}{l}\text { non-covalent } \\
(\pi-\pi \\
\text { interaction })\end{array}$ & acetonitrile & $\begin{array}{l}\text { oxidative } \\
\text { coupling } \\
\text { of benzylamines }\end{array}$ & $\begin{array}{l}\text { hybrid visible light } \\
\text { driven photocatalyst }\end{array}$ & [77] \\
\hline bpy & bentonite & $\begin{array}{l}\text { non-covalent } \\
(\pi-\pi \\
\text { interaction })\end{array}$ & - & $\begin{array}{l}\text { limonene } \\
\text { oxidation }\end{array}$ & $\begin{array}{l}\text { selective catalyst for } \\
\text { oxidation of limonene }\end{array}$ & [78] \\
\hline $\begin{array}{l}\text { iron(II) phthalocyanine } \\
\text { iron(II) } 1,2,3,4,8,9,10,11,15 \text {, } \\
16,17,18,22,23,24,25- \\
\text { hexadeca(chloro) } \\
\text { phthalocyanine }\end{array}$ & double-walled CNTs & $\begin{array}{l}\text { covalent } \\
\text { bonds }\end{array}$ & $\begin{array}{l}\text { isopropyl } \\
\text { alcohol }\end{array}$ & $\begin{array}{l}\text { reduction of } \\
\mathrm{O}_{2} \text { in an } \\
\text { acid medium }\end{array}$ & $\begin{array}{l}\text { efficient and } \\
\text { inexpensive catalyst } \\
\text { for the oxygen } \\
\text { reduction reaction }\end{array}$ & [79] \\
\hline $\begin{array}{l}\text { iron(II) } \\
\text { tetraphenylporphyrin }\end{array}$ & $\begin{array}{l}\text { metal } \\
\text { organic framework }\end{array}$ & $\begin{array}{l}\text { covalent } \\
\text { bonds }\end{array}$ & DMF & $\mathrm{CO}_{2}$ reduction & $\begin{array}{l}\text { high-surface } \\
\text { concentration } \\
\text { catalysts for } \\
\mathrm{CO}_{2} \text { reduction } \\
\end{array}$ & [80] \\
\hline $\begin{array}{l}\text { (4-(3-((bis(pyridin- } \\
\text { 2-ylmethyl)amino)methyl)- } \\
\text { 4hydroxybenzamido) } \\
\text { phenyl)phosphonic acid (a) }\end{array}$ & $\mathrm{TiO}_{2}, \mathrm{SrTiO}_{3}$ & non-covalent & $\begin{array}{l}\text { ethanol/ } \\
\text { water }\end{array}$ & $\begin{array}{l}\text { photocatalytic } \\
\text { hydrogen } \\
\text { generation }\end{array}$ & $\begin{array}{l}\text { Highly active and } \\
\text { stable photocatalytic } \\
\text { system for } \\
\text { hydrogen generation }\end{array}$ & [81] \\
\hline PIPhen & carbon powder & non-covalent & $\mathrm{KOH}$ & $\begin{array}{l}\text { ORR in } \\
\text { alkaline } \\
\text { electrolyte }\end{array}$ & $\begin{array}{l}\text { novel non-noble metal } \\
\text { ORR catalyst as } \\
\text { alternative for Pt } \\
\text { catalyst in fuel cell }\end{array}$ & [10] \\
\hline $\begin{array}{l}N \text {-doped porous carbon } \\
\text { that anchors both } \\
\text { atomically dispersed Fe- } \mathrm{N}_{4} \\
\text { sites and } \mathrm{Fe} \text { atomic clusters } \\
\left(\mathrm{Fe}_{\mathrm{AC}} @ \mathrm{Fe}_{\mathrm{SA}}-\mathrm{N}-\mathrm{C}\right)\end{array}$ & $\begin{array}{l}\text { (4-aminophenyl) } \\
\text { benzene- } \\
\text { terephthaldehyde } \\
\text { covalent organic } \\
\text { framework } \\
\text { (TAPB-PDA COF) }\end{array}$ & covalent & $\begin{array}{l}\mathrm{KOH}, \\
\text { methanol }\end{array}$ & ORR & $\begin{array}{l}\text { alternative catalyst to } \\
\text { noble metal-based } \\
\text { catalysts for highly } \\
\text { efficient ORR }\end{array}$ & [11] \\
\hline $\begin{array}{l}\text { graphene encapsulated } \\
\mathrm{Fe} / \mathrm{Fe}_{3} \mathrm{C} \text { nanocrystals- } \\
\mathrm{Fe}-\mathrm{Nx} \text { configurations } \\
\text { (Fe@C-FeNC) }\end{array}$ & - & - & $\begin{array}{l}\mathrm{HClO}_{4} \\
\text { with } \\
\text { addition } \\
\text { of } \mathrm{NaSCN} \text {, } \\
\mathrm{KOH}\end{array}$ & ORR & $\begin{array}{l}\text { high-performance } \\
\text { non-precious metal } \\
\text { catalyst for ORR }\end{array}$ & [12] \\
\hline $\begin{array}{l}\text { meso-tetra (4-pyridyl) } \\
\text { porphyrin }\end{array}$ & porous carbon & $\begin{array}{l}\text { noncovalent } \\
\text { bonds }\end{array}$ & $\begin{array}{l}\mathrm{KOH} \\
\mathrm{HClO}_{4}\end{array}$ & ORR & $\begin{array}{l}\text { trace-metal catalyst } \\
\text { toward ORR in both } \\
\text { alkaline and } \\
\text { acidic mediums }\end{array}$ & [83] \\
\hline $\begin{array}{l}\text { iron } \\
\text { nanoparticle/hierarchical } \\
\text { carbon framework (Fe } \\
\text { NP/3D-C) }\end{array}$ & - & - & $\mathrm{KOH}$ & ORR & $\begin{array}{l}\text { electrocatalyst with } \\
\text { superior ORR } \\
\text { catalytic } \\
\text { activity and excellent } \\
\text { durability with large } \\
\text { mass activity }\end{array}$ & [84] \\
\hline
\end{tabular}


Table 2. Cont

\begin{tabular}{|c|c|c|c|c|c|c|}
\hline Ligand/Catalyst & $\begin{array}{l}\text { Type of Solid } \\
\text { Substrate }\end{array}$ & $\begin{array}{l}\text { Type of } \\
\text { Attachment }\end{array}$ & Solvent & $\begin{array}{l}\text { Type of } \\
\text { Reaction }\end{array}$ & Product & Ref. \\
\hline $\begin{array}{l}\text { 1,10-phenanthroline, bpy, } \\
2,2^{\prime}, 6^{\prime}, 2^{\prime \prime} \text {-terpyridine, } \\
\text { pyridinebisbenzimidazole }\end{array}$ & carbon & $\begin{array}{l}\text { noncovalent } \\
\text { bonds }\end{array}$ & THF & $\begin{array}{l}\text { chemoselective } \\
\text { transfer } \\
\text { hydrogenation } \\
\text { of nitroarenes } \\
\text { to anilines }\end{array}$ & $\begin{array}{l}\text { durable and reusable } \\
\text { catalysts for transfer } \\
\text { hydrogenation of } \\
\text { nitroarenes to anilines } \\
\text { with unique } \\
\text { selectivity for the } \\
\text { nitro group reduction }\end{array}$ & [86] \\
\hline 1,10-phenanthroline & carbon & $\begin{array}{l}\text { noncovalent } \\
\text { bonds }\end{array}$ & $\begin{array}{l}\text { THF/water, } \\
\text { dioxane/ } \\
\text { water, THF, } \\
\text { dioxane, } \\
\text { water }\end{array}$ & $\begin{array}{l}\text { reductive } \\
\text { amination } \\
\text { with hydrogen } \\
\text { between } \\
\text { nitroarenes } \\
\text { and aldehydes }\end{array}$ & $\begin{array}{l}\text { efficient catalyst for } \\
\text { synthesis of } \\
\text { secondary amines }\end{array}$ & [87] \\
\hline 1,10-phenanthroline & carbon & $\begin{array}{l}\text { noncovalent } \\
\text { bonds }\end{array}$ & THF/water & $\begin{array}{l}\text { hydrogenation } \\
\text { of nitroarenes }\end{array}$ & $\begin{array}{l}\text { efficient catalyst for } \\
\text { hydrogenation of } \\
\text { nitroarenes } \\
\text { under water-gas shift } \\
\text { reaction conditions }\end{array}$ & [89] \\
\hline 1,10-phenanthroline & carbon & $\begin{array}{l}\text { noncovalent } \\
\text { bonds }\end{array}$ & $\begin{array}{l}t \text {-amyl } \\
\text { alcohol }\end{array}$ & $\begin{array}{l}\text { synthesis of } \\
\text { nitriles from } \\
\text { alcohols and } \\
\text { aqueous } \\
\text { ammonia } \\
\text { using } \\
\text { molecular } \\
\text { oxygen }\end{array}$ & $\begin{array}{l}\text { efficient catalyst for } \\
\text { synthesis of } \\
\text { substituted and } \\
\text { functionalized } \\
\text { benzonitriles, } \\
\text { heterocyclic nitriles } \\
\text { and aliphatic nitriles }\end{array}$ & [90] \\
\hline polyaniline-derived Fe-N-C & - & - & $\mathrm{KOH}$ & ORR & $\begin{array}{l}\text { non-precious metal } \\
\text { catalysts for the ORR } \\
\text { with performance in a } \\
\text { practical anion } \\
\text { exchange membrane } \\
\text { fuel cell }\end{array}$ & [92] \\
\hline Fe-N-C nanostructures & $\begin{array}{l}\text { CNT, carbon black, } \\
\text { graphene oxide } \\
\text { SWCNT }\end{array}$ & - & $\mathrm{HClO}_{4}$ & ORR & $\begin{array}{l}\text { efficient substituent of } \\
\text { commercial } \mathrm{C} / \mathrm{Pt} \\
\text { catalysts }\end{array}$ & [93] \\
\hline Fe-N-C nanostructures & $\mathrm{SiO}_{2}, \mathrm{Zn}$ & $\begin{array}{l}\text { noncovalent } \\
\text { bonds }\end{array}$ & $\mathrm{KOH}$ & ORR & $\begin{array}{l}\text { efficient substituent of } \\
\text { commercial C/Pt } \\
\text { catalysts }\end{array}$ & [94] \\
\hline
\end{tabular}

(a) fluorescein as a chromophore and trimethylamine as an electron donor.

\subsection{Nitrogen-Containing Iron Complexes Anchored on a Solid Support (Non-Treated Thermally)}

In order to combine intrinsic activity and selectivity of the molecular catalyst with chemical and thermal robustness as well as ease of separation of heterogeneous systems, some Fe complexes with $\mathrm{N}$-containing ligands (including macrocycles, e.g., porphyrins, phtalocyanines, and non-macrocycles, e.g., bipyridine, phenanthroline, polypyrrole) were anchored to the porous inorganic support (including zeolites, clays, alumina, titania, silica, carbon) or organic polymers (including metal organic frameworks, MOFs). The researches were frequently inspired by biological systems [95]. A comprehensive discussion of this research is beyond the scope of this review, however, we will shortly illustrate some recent trends 
in the research by selected examples. There are generally three strategies of immobilization: including physical adsorption, covalent attachment, and integration into three-dimensional porous frameworks.

The undeniable merit of the adsorption method is its simplicity. The method frequently exploits $\pi-\pi$ interactions or electrostatic ones. Maurin and Robert utilized this method for preparation of a $\mathrm{CO}_{2}$ reduction electrocatalyst [76]. They modified the known molecular catalyst of $\mathrm{CO}_{2}$ to $\mathrm{CO}$ reduction, tetraphenyl iron porphyrin, removing one phenyl group and appending a pyrene unit as immobilizing linkage. The compound was attached to carbon nanotubes (CNTs) and then to a glassy carbon electrode. Thus synthesized catalyst was selective, stable, fast, and afforded low $\mathrm{CO}_{2}$ reduction potential in unbuffered water at a neutral $\mathrm{pH}$.

Another example exploiting the same principle of immobilization was anchoring iron(II) trisbipyridine complex to the nanoporous graphitic carbon nitride support [77]. Heterogenization enhances photocatalytic activity in oxidative coupling of benzylamines under mild conditions when $\mathrm{O}_{2}$ was used as an oxidant, and a household white LED as a light source. Using a similar principle, 2,2'-bipyridine (bpy) complexes of $\mathrm{Mn}(\mathrm{II})$ and $\mathrm{Fe}(\mathrm{II})$ were adsorbed on bentonite. The prepared material was used for limonene oxidation by $\mathrm{O}_{2}$ [78]. The reaction was more selective than the homogeneous one.

The most important feature of catalyst covalent immobilization is a strong attachment. There are many studies following this strategy. Recio et al. [79] reasoned that the active site of Fe phthalocyanine (FePc) and Fe hexadecachloro-phthalocyanine [16(Cl)FePc] complexes, chemically anchored to carbon nanotubes by pyridine, axial, fifth ligand, is harder compared to a physisorbed catalyst. Therefore, according to the hard-soft acid base principle, it should promote high activity for the ORR in an acidic environment because dioxygen is a hard base. They found that electron-withdrawing groups (like $\mathrm{Cl}$ and axial, anchoring pyridine ligand) increase activity of the catalyst in ORR. The coordination allows for decoupling of the metal from the electrode, hindering the production of undesired $\mathrm{H}_{2} \mathrm{O}_{2}$ by-product.

Functionalized Fe-porphyrines were immobilized into metal organic framework MOF-525 by electrophoresis, creating redox-active linkers [80]. This strategy increased surface availability of the corresponding homogeneous catalyst 600 times, resulting in 2-3 fold increase in $\mathrm{CO}_{2}$ reduction current, when the obtained porous material was immobilized on an electrode surface.

In the recent study, an iron(III) complex with polypyridyl, phosphonic acid functionalized ligand was assembled on $\mathrm{TiO}_{2}$ and $\mathrm{SrTiO}_{3}$ [81]. When irradiated in a solution of fluorescein and trimethylamine (sacrificial donor) the system produced hydrogen, with TON $>7800$ in $71 \mathrm{~h}$.

Multiple $N$ active sites ligand, 2-(2-(4-(1H-imidazo[4,5-f][1,10]phenanthrolin-2-yl)pyridin-2yl)pyridin-4-yl)-1- $H$-imidazo[4,5-f][1,10]phenanthroline (PiPhen) was synthesized and its iron(II) complex, was loaded on carbon powder in the form of coordination polymer [10]. The material, when deposited on platinum carbon electrode showed high electrocatalytic activity in ORR in an alkaline electrolyte with low yield for $\mathrm{H}_{2} \mathrm{O}_{2}$.

Encapsulation in porous material allows for engineering of electronic features of active sites via structural adjustment of the framework. Due to high porosity, the entrapped catalyst molecules are easily available for the substrate. Mixed ligand complexes of bpy and 1,10-phenanthroline with iron(III) and nickel(II) were encapsulated into a NaY zeolite cage by ship in bottle method, i.e., utilizing the size of complex formed in the zeolite cage [82]. Based on density functional theory (DFT) calculations they predicted high reactivity of such immobilized species and showed that the material catalyzes oxidation of 2-phenyl phenol by $\mathrm{H}_{2} \mathrm{O}_{2}$. They also found that the catalyst can be used more than three times without losing catalytic efficiency.

\subsection{Iron-Nitrogen Functionalities on a Solid Support (Obtained by Thermal Treatment of Precursors)}

The discovery of Jasinski [9] triggered a new research trend. After a period of time it was demonstrated that thermal treatment increases activity and stability of the M-N-C catalyst $[96,97]$.

Since that time many pyrolyzed Me-N-C systems were investigated, including Fe-N-C ones. It was also found that apart from Fe complexes with $\mathrm{N}$-containing macrocycles, other available sources of 
Fe (e.g., salts), C (any organic compound), and $\mathrm{N}$ can be precursors of the catalyst. The sources of $\mathrm{N}$ can be organics, e.g., bipyridine, phenanthroline, terpyridine, pyrrole, imidazole melamine, polymers (e.g., pylyaniline, polydopamine); and inorganics, like sodium azide or ammonia. The typical substrates are carbonaceous materials (e.g., carbon black, carbon nanotubes, carbon nanofibers (CNFs), reduced graphite oxide (rGO), graphene), which frequently display good electrical conductivity. These nanomaterials offer also a highly developed surface, porous structure, or are rich in structural defects. Reviews of carbon-supported Fe-N-C catalysts and/or electrocatalysts have recently been published [98-100].

There are two basic synthetic methods for carbon-based iron-nitrogen catalysts: pyrolysis and hydrothermal carbonization (HTC). In the pyrolysis method the precursors (composed of carbon, nitrogen and iron, and sometimes other elements, e.g., sulfur or zinc), usually immobilized on solid substrates, are heated in inert gas atmosphere at a temperature usually in the range of $600-1100{ }^{\circ} \mathrm{C}$. Hydrothermal carbonization (HTC) consists in heating a precursor in water solvent at moderate temperatures $\left(200^{\circ} \mathrm{C}\right)$ in an autoclave.

Thermal decomposition results in a formation of $\mathrm{FeN}_{\mathrm{x}}$ active sites and usually other structures, including $\mathrm{Fe}$, iron oxide, or carbide phases. The active sites of most materials have not been clearly identified so far [101]. Probably, the majority of the early Fe-N-C catalysts obtained by thermal treatment are dozens of nanometers in size, corresponding to the definition of a large nanoparticle (LNP). Owing to the development of synthetic methods and analytic instruments, single-site materials have recently been synthesized [100,102-109]. Such ideal catalysts are characterized by the highest exposure of active sites, good availability for substrate and minimized metal utilization. However, some results show enhanced ORR after incorporating nanoclusters of Fe to single-atom Fe-N-C catalyst [11], others emphasize the

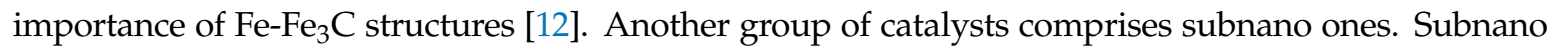
materials are usually defined as the ones of atomic-level size and showing unique, size-related properties compared to their larger nano-counterparts, or just ones of dimensions smaller than LNPs $[57,110]$. Some subnano Fe-N-C catalytic structures have been recently obtained (Figure 4a) [83,84].
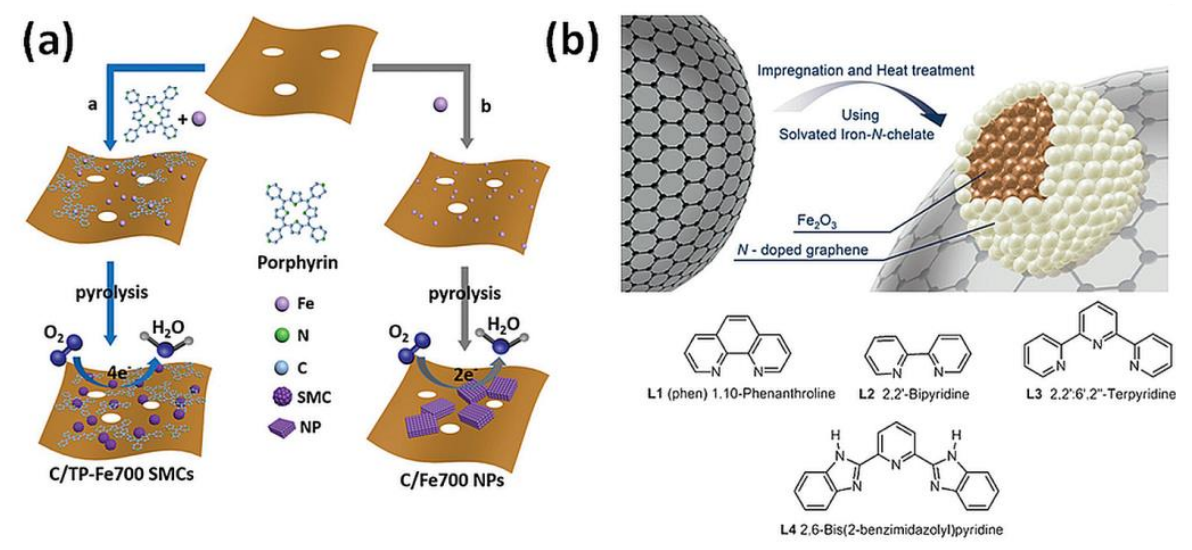

(c)

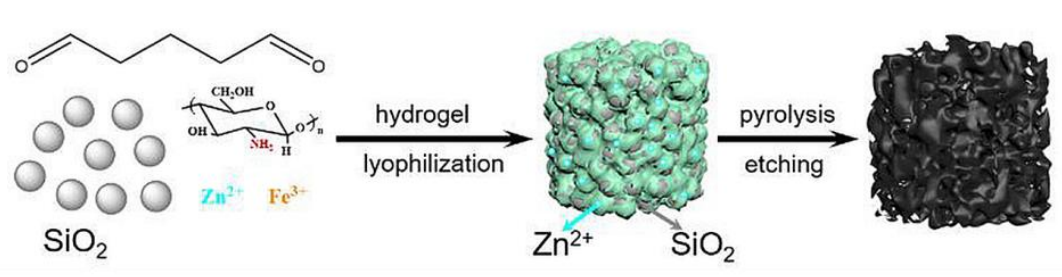

Figure 4. Heterogeneous catalysts: (a) Synthetic routes for the preparation of iron $(\mathrm{Fe})$ single clusters immobilized on $N$-doped porous carbon (C/TP-Fe700 SMCs) and iron-based nanoparticles (C/Fe700 NPs) [83]. Reprinted with permission from WILEY-VCH Verlag GmbH \& Co. KGaA, Copyright 2018. (b) Preparation of $\mathrm{Fe}_{2} \mathrm{O}_{3}$-based nanocatalysts by pyrolysis on carbon support [91]. Reprinted with permission from WILEY-VCH Verlag GmbH \& Co. KGaA, Copyright 2015. (c) Multiscale porous Fe-N-C catalyst produced with $\mathrm{SiO} 2$ and $\mathrm{Zn}$ as co-templates [94]. Reprinted with permission from Royal Society of Chemistry, Copyright 2019. 
Recently a review concerning M-N-C catalysts for ORR was published by Osmieri [111]. The clear division of synthetic strategies that was recognized for these materials perfectly covers most Fe-N-C catalysts, not only the ones used for ORR.

The first synthetic method consists of thermal treatment of carbon support and nitrogen-containing molecules. This strategy resulted in spectacular examples of catalysis in the field of organic chemistry. Beller's group's [85] seminal discovery of a new heterogeneous catalyst for important organic reactions opened new vistas of potential applications. The catalyst, obtained by pyrolysis of nitrogen precursor and iron salt, affords selective hydrogenation (with $\mathrm{H}_{2}$ ) of nitroarenes to anilines, at mild conditions with high yields. $\mathrm{N}$-containing ligand and pyrolysis temperature have been optimized. The best catalytic material was obtained by pyrolysis at $800^{\circ} \mathrm{C}$ of iron-phenanthroline complex adsorbed on carbon black. Later it was demonstrated that the catalyst exhibited remarkable activity for the activation of formic acid in the transfer hydrogenation of nitroarenes to anilines [86]. Next, an environmentally friendly method for the selective synthesis of secondary amines, by hydrogenation of nitroarenes as well as imines was proposed [87] and later for the synthesis of tertiary amines [88]. Recently the utilization of this catalyst under water-gas shift conditions [89] and also for the oxidation of primary alcohols or primary amines to nitriles with dioxygen has been demonstrated (Figure $4 b$ ) $[86,90]$.

The second synthetic strategy utilizes a nitrogen-containing polymer. PANI-derived Fe-N-C catalyst was developed by sonication of ferric chloride with aniline and carbon black, instead of using traditional, expensive ammonium persulfate for polymerization [92]. After pyrolysis, carbonization of aniline by heat treatment (at various temperatures in the range $300-900^{\circ} \mathrm{C}$ ), removal of impurities and iron oxide by acid leaching, and graphitization of the remaining carbon by a second heat treatment at $90{ }^{\circ} \mathrm{C}$, the best catalyst (pyrolyzed at $700^{\circ} \mathrm{C}$ ) displayed half-wave potential for ORR only $10 \mathrm{mV}$ less than commercial $\mathrm{Pt} / \mathrm{C}$ catalyst and showed outstanding performance in anion exchange membrane fuel cell.

Pyrolyzed Fe-N-C materials are also investigated for potential application in zero-carbon fuels generation. Recently polyaniline derived Fe-N-C catalysts were synthesized [112] and the ratio of different $N$ functionalities was tuned according to the pyrolysis temperature (in the range $750-1050^{\circ} \mathrm{C}$ ). A larger amount of formed $\mathrm{FeN}_{\mathrm{x}}$ sites, formed at higher temperatures was responsible for higher selectivity towards $\mathrm{CO}_{2} \mathrm{RR}$.

Another approach exploits carbon nanotubes. Polypyrrole coated CNTs, subsequently enriched in highly concentrated Fe atoms prepared by simultaneous adsorption of $\mathrm{Fe}^{3+}$ and $\mathrm{Zn}^{2+}$ cations, and pyrolyzed at $900{ }^{\circ} \mathrm{C}$ in gas ammonia were developed [93]. The material exhibited a half-wave potential of ORR comparable to commercial $\mathrm{Pt} / \mathrm{C}$ catalyst in acidic water solution. Consequently, they used this synthetic method for carbon cloth (CC) and also for flexible films of single-wall carbon nanotubes (SWCNT), which both displayed even better ORR performance than $\mathrm{Pt} / \mathrm{C}$.

The third group of catalysts derives from application of Hard Template Method and utilizes silica template and organic precursors. The method takes advantage of the high porosity of the silica template. The presence of silica obviates the need for carbon support. After the carbonization of the precursors, the silica scaffolding is removed by leaching with HF or a strong base, leaving its excellent porosity in the structure of a formed catalyst. A dual-template method of synthesizing porous Fe-N-C catalyst has been developed [94]. The dual-template was prepared by mixing glutaraldehyde and chitosan (the constituents of the first template) with $\mathrm{SiO}_{2}$, porous nanoparticles (second template) (Figure 4c). Finally, the iron precursor $\left(\mathrm{FeCl}_{3}\right)$ was added to the mixture and zinc nitrate to increase porosity due to evaporation of $\mathrm{Zn}$ during heat treatment. The resulting hydrogel was freeze-died, pyrolyzed, and leached with HF. The material with multiscale porosity displayed better performance in ORR than commercial C/Pt catalysts, as measured by rotating disc electrode (RDE) method.

Another synthetic method utilizes metal-organic frameworks (MOFs). MOFs are porous, highly ordered, crystalline structures, composed of metal ions and organic linkers. The positive charge of this net is balanced by negative counter ions, located in the pores, together with solvent molecules. The metal ions and the linkers can be adjusted in a way which allows for the desired structure and 
composition of MOF. This structure can partially remain in the material after heat treatment. Recently Wang et al. developed a "MOF-protective-pyrolysis" strategy [113]. The iron- and nitrogen-containing metal-organic framework $\mathrm{NH}_{2}$-MIL-101-Fe of excellent, regular porosity was embedded in zinc-based ZIF-8 (another MOF, an additional source of $\mathrm{N}$ and $\mathrm{C}$ ). The material they obtained after pyrolysis, containing basically the structure of MOF and some carbon nanotubes, displayed good performance in ORR. The authors proposed a mechanism assuming Fenton reaction, whereby formed $\mathrm{FeN}_{4}$ centres react with hydrogen peroxide affording active carbon radicals of strong adsorption to $\mathrm{O}_{2}$, and consequently accelerating ORR.

Additional possibilities can be created by utilizing additional precursors during the synthesis of Fe-N-C catalyst with MOFs. A highly porous structure of MOF can contain, e.g., iron complexes with nitrogen-containing ligands. For example, Fe-phenanthroline has been exploited by Li et al. [114] ZIF-8 was calcined at $400^{\circ} \mathrm{C}$ and such prepared material was a substrate for Fe-phenanthroline complex. After two consecutive heat treatments at $1050{ }^{\circ} \mathrm{C}$ (at $\mathrm{Ar}$ and $\mathrm{NH}_{3}$ atmosphere) the material was leached with hydrochloric acid. The catalyst not only showed high activity in ORR but also intrinsic immunity to poisoning by chlorides.

Two-dimensional hierarchical Fe-N-C materials were demonstrated to be highly effective electrocatalysts for ORR in Zn-air batteries [115], enabling ultrahigh specific capacity. Such configuration was obtained by confined-space pyrolysis of assembled precursors, using GO, ZIF-8 and iron salt.

The other method used for the synthesis of Fe-N-C materials exploits vapour deposition (CVD). Iron is usually used as a catalyst in the CVD method of carbon nanotubes production and frequently considered contamination, responsible for its toxicity [116]. Deng et al. showed earlier that encapsulated Fe or FeCo NPs in CNTs can activate $\mathrm{O}_{2}$ on the outer surface of the nanotube, while the mentioned nanoparticles are preserved against leaching in the acidic medium $[117,118]$. Inspired by this discovery they designed the catalytic material, encapsulating Fe, Co, and FeCo alloy NPs via the CVD method in $N$-doped (using pyridine vapours at $700{ }^{\circ} \mathrm{C}$ ) CNTs [119]. The catalyst displayed long-time durability and high activity in HER.

\section{Iron-Based Catalyst in Controlled Radical Polymerization}

Transition metals have become a fundamental catalyst in controlled radical polymerization represented by reversible deactivation radical polymerization (RDRP) methods, especially leading in the field-ATRP technique. The success of transition metals in ATRP results from an ability to lend electrons or withdraw electrons from the reagent, and thus change the oxidation states as described in details in the previous sections $[120,121]$. This feature is an integral part of the ATRP mechanism based on the reversibility of catalyst oxidation states, and thus re-forms the catalyst in its lower oxidation state (activator). Metal in the form of the activator reacts with alkyl halide/dormant (macro)molecular species forming deactivators, higher oxidation state transition metal complexes and propagating radicals, followed by the addition of monomer(s) and thus chain growth [122]. Copper complexes are the most extensively studied catalyst system in ATRP $[123,124]$. However, due to the disadvantages of the copper catalyst, e.g., contamination of polymers with stable catalytic complex-essential limitation in the context of large-scale industrial manufacture and specialist applications-the researchers are still studying the effect of various metals as catalysts on polymerization. In this context, special attention was attracted by iron-based catalysts. This solution is characterized by low toxicity, and thus environmental friendliness, low cost, and abundance $[22,125,126]$. There have been many papers describing the use of the iron-based catalyst in ATRP in preparation of both homopolymers [127-130], as a complex architecture [131,132], especially hybrid materials [133-136] with predetermined characteristics for specialized use (Table 3). 
Table 3. Preparation of functional materials by of iron-mediated atom transfer radical polymerization.

\begin{tabular}{|c|c|c|c|c|c|}
\hline Catalytic Complex & Initiator & Monomer & Solvent & Final Product & Ref. \\
\hline $\mathrm{Fe}^{\mathrm{II}} \mathrm{Cl}_{2} / \mathrm{SA}$ & $\mathrm{CPN}, \mathrm{MCPN}$ & $\begin{array}{l}\text { maleic acid, } \\
N \text {-mropylacrylamide, } \\
N \text {-butylacrylamide, } \\
N \text {-hexylacrylamide, } \\
N \text {-acryloylbenzamide }\end{array}$ & $o$-xylene & $\begin{array}{l}\text { maleic anhydride } \\
\text { copolymers with } \\
\text { antiscalant performance }\end{array}$ & [137] \\
\hline $\mathrm{Fe}^{\mathrm{IIII}} \mathrm{Cl}_{3} \cdot 6 \mathrm{H}_{2} \mathrm{O} / \mathrm{SSA}^{(\mathrm{a})}$ & EBIB, DFMA & IBMA, HEMA & butanone & $\begin{array}{l}\text { fluorinated amphiphilic } \\
\text { copolymers }\end{array}$ & [138] \\
\hline $\mathrm{Fe}^{\mathrm{II}} \mathrm{Br}_{2} / \mathrm{Fe}^{\mathrm{III}} \mathrm{Br}_{3} / \mathrm{TBABr}$ & PBiBEM & $n \mathrm{BA}, \mathrm{St}, \mathrm{DEGA}$ & anisole & $\begin{array}{l}\text { amphiphilic molecular } \\
\text { bottlebrushes }\end{array}$ & [131] \\
\hline $\mathrm{Fe}^{\mathrm{IIII}} \mathrm{Br}_{3} / \mathrm{IDipp}{ }^{(\mathrm{b})}$ & $\mathrm{TA}-\mathrm{Br}$ & $n \mathrm{BA}$ & DMF & $\begin{array}{l}\text { star-shaped polymers as } \\
\text { polyelectrolytes } \\
\text { precursors }\end{array}$ & [132] \\
\hline $\mathrm{Fe}^{\mathrm{III}} \mathrm{Cl}_{3} \cdot 6 \mathrm{H}_{2} \mathrm{O} / \mathrm{TDA}-1^{\text {(a) }}$ & $\begin{array}{l}\text { brominated } \\
\text { MIONPs }\end{array}$ & VBK, PEGMA & $\mathrm{DMF}$ & $\begin{array}{l}\text { fluorescent/magnetic } \\
\text { nanoparticles for } \\
\text { magnetic resonance } \\
\text { imaging (MRI) }\end{array}$ & [133] \\
\hline $\mathrm{Fe}^{\mathrm{III}} \mathrm{Cl}_{3} \cdot 6 \mathrm{H}_{2} \mathrm{O} / \mathrm{TDA}-1^{(\mathrm{a})}$ & $\mathrm{Fe}_{3} \mathrm{O}_{4} @ \mathrm{SiO}_{2}-\mathrm{Br}$ & PEGMA $_{475}, t$ BA & DMF & $\begin{array}{l}\text { magnetic nanoparticles } \\
\text { with near-infrared } \\
\text { pH-activatable } \\
\text { fluorescence to visualize } \\
\text { the solid tumor in vivo }\end{array}$ & [135] \\
\hline $\mathrm{Fe}^{\mathrm{III}} \mathrm{Cl}_{3} \cdot 6 \mathrm{H}_{2} \mathrm{O} / \mathrm{PPh}_{3}{ }^{(\mathrm{a})}$ & $\mathrm{SiO}_{2}-\mathrm{Br}$ & MMA, PEGMA 300 & DMF & $\begin{array}{l}\text { amphiphilic silica } \\
\text { nanoparticles }\end{array}$ & [139] \\
\hline $\mathrm{Fe}^{\mathrm{III}} \mathrm{Cl}_{3} / \mathrm{IDA}^{(\mathrm{a})}$ & SG-Cl & MMA, BMA & DMF & $\begin{array}{l}\text { high oil-absorption } \\
\text { resins }\end{array}$ & [134] \\
\hline $\mathrm{Fe}^{\mathrm{III}} \mathrm{Cl}_{3} \cdot 6 \mathrm{H}_{2} \mathrm{O} / \mathrm{TDA}-1^{(\mathrm{a})}$ & MWCNTs-Br & St, MMA, PEGMA & DMF & $\begin{array}{l}\text { hybrid multiwall carbon } \\
\text { nanotubes material for } \\
\text { biomedical applications }\end{array}$ & [136] \\
\hline $\begin{array}{l}\mathrm{Fe}^{\mathrm{III}} \mathrm{Cl}_{3} \cdot 6 \mathrm{H}_{2} \mathrm{O} / \mathrm{TDA}-1, \\
\mathrm{Fe}^{\mathrm{III}} \mathrm{Cl}_{3} \cdot 6 \mathrm{H}_{2} \mathrm{O} / \mathrm{PPh}_{3} \text { (a) }\end{array}$ & $\begin{array}{l}\mathrm{SEBS} @ \mathrm{CH}_{2} \mathrm{Cl} \\
\text { (chloromethylated } \\
\text { SEBS) }\end{array}$ & MMA, St, $t$ BA & THF & $\begin{array}{l}\text { SEBS with improved } \\
\text { compatibility with other } \\
\text { materials }\end{array}$ & [140] \\
\hline $\mathrm{Fe}^{\mathrm{III}} \mathrm{Cl}_{3} \cdot 6 \mathrm{H}_{2} \mathrm{O} / \mathrm{PPh}_{3}{ }^{\text {(a) }}$ & $\begin{array}{l}\text { CTSNSs-Br } \\
\text { (brominated } \\
\text { CTSNSs) }\end{array}$ & MMA, PEGMA & DMF & $\begin{array}{l}\text { CTSNSs hybrid } \\
\text { materials with potential } \\
\text { biomedical use }\end{array}$ & [141] \\
\hline
\end{tabular}

(a) $\mathrm{Fe}^{\mathrm{III}} \mathrm{Br}_{3}$ reduced to $\mathrm{Fe}^{\mathrm{II}} \mathrm{Br}_{2}$ by ascorbic acid as a reducing agent; ${ }^{\text {(b) }} \mathrm{Fe}^{\mathrm{III}} \mathrm{Br}_{3}$ reduced to $\mathrm{Fe}^{\mathrm{II}} \mathrm{Br}_{2}$ by electric current.

Considering the preparation of functional copolymer materials by iron-catalyzed ATRP, precisely-defined maleic anhydride copolymers $(\Theta=1.00-1.11)$ from $n$-alkylacrylamide and maleic anhydride monomers were prepared with the use of iron(II) chloride $\left(\mathrm{Fe}^{\mathrm{II}} \mathrm{Cl}_{2}\right)$ as a catalyst and also inexpensive and nontoxic acid (succinic acid, SA) as a ligand [137]. Maleic acid-based copolymers, known as an effective material for desalination of seawater, improved by modification with other monomers showed high scale inhibition efficiency. Another "green" ligand, namely sulfosalicylic acid (SSA) was used to prepare fluorinated amphiphilic copolymers via activator generated by electron transfer (AGET) ATRP with iron(III) chloride hexahydrate $\left(\mathrm{Fe}^{\mathrm{III}} \mathrm{Cl}_{3} \cdot 6 \mathrm{H}_{2} \mathrm{O}\right)$ as a catalyst. Comparing to the classic ATRP system, AGET ATRP uses a reducing agent to form an active catalyst and thus overcomes a few drawbacks, e.g., limited exposure to oxygen can be tolerated. The preparation of amphiphilic materials was conducted with regeneration of Fe(II) by ascorbic acid (AsAc). Fluoride segments give an excellent hydrophobicity, thermal and chemical stability, biological inertness, oleophobic and low dielectric constant, while the addition of hydrophilic polymer segment creates the possibility to self-assemble in selective solvents and form different morphologies, desired in a wide range of specialist application [138]. 
Researchers' interest in polymers with branched architecture characterized by unique supramolecular structure especially for medical and pharmaceutical applications leads to the application of iron-catalyzed ATRP for the synthesis of star-shaped polymers [132] and bottlebrushes [131]. Iron(II) bromide/iron(III) bromide/tetrabutylammonium bromide $\left(\mathrm{Fe}^{\mathrm{II}} \mathrm{Br}_{2} / \mathrm{Fe}^{\mathrm{III}} \mathrm{Br}_{3} / \mathrm{TBABr}\right)$ catalyzed the synthesis of molecular bottlebrushes with densely grafted poly(n-butyl acrylate) (PnBA), PSt, or thermoresponsive poly(di(ethylene glycol) ethyl ether acrylate)) (PDEGA) side chains and poly[2-(2-bromoisobutyryloxy)ethyl methacrylate] (PBiBEM) backbone with 400 initiation sites [131]. Star-like macromolecules were prepared by a representative for an externally-controlled ATRP technique, simplified electrochemically mediated ATRP (seATRP) with $\mathrm{Fe}^{\mathrm{III}} \mathrm{Br}_{3} / \mathrm{IDipp}$ (IDipp = 1,3-bis(2,6-diisopropylphenyl)imidazol-2-ylidene), as a catalyst system. This naturally-derived complex material consists of a tannic acid core and twenty hydrophobic PBA functional arms, prone for facile copolymerization by polyacrylates, e.g., stimuli-responsive polymers with potential use as drug and gene delivery systems [132].

Recently, a major area of research and technological development in the field of polymer synthesis is focused on hybrid materials composed of functional polymers as an organic segment and inorganic nanostructured compounds $[142,143]$. In this context, the introduction of metal oxide nanoparticles in the polymeric nanocomposites provides advanced technological materials has attracted special attention due to their multifunctional properties as electronic, optical, and unique mechanical characteristics [144]. Magnetic iron oxide nanoparticles (MIONPs) as a high-performance material are extensively used in medicine as drug delivery systems, in hyperthermia techniques, tissue repair, and for visualization by magnetic resonance imaging (MRI) [145]. Iron(III)-mediated AGET ATRP with AsAc as a reducing agent was utilized to modify functionalized MIONPs with fluorescent monomer 9-(4-vinylbenzyl)-9H-carbazole (VBK), subsequently covered with hydrophilic monomer poly(ethylene glycol) methyl ether methacrylate (PEGMA) to improve water solubility (Figure 5) [133].
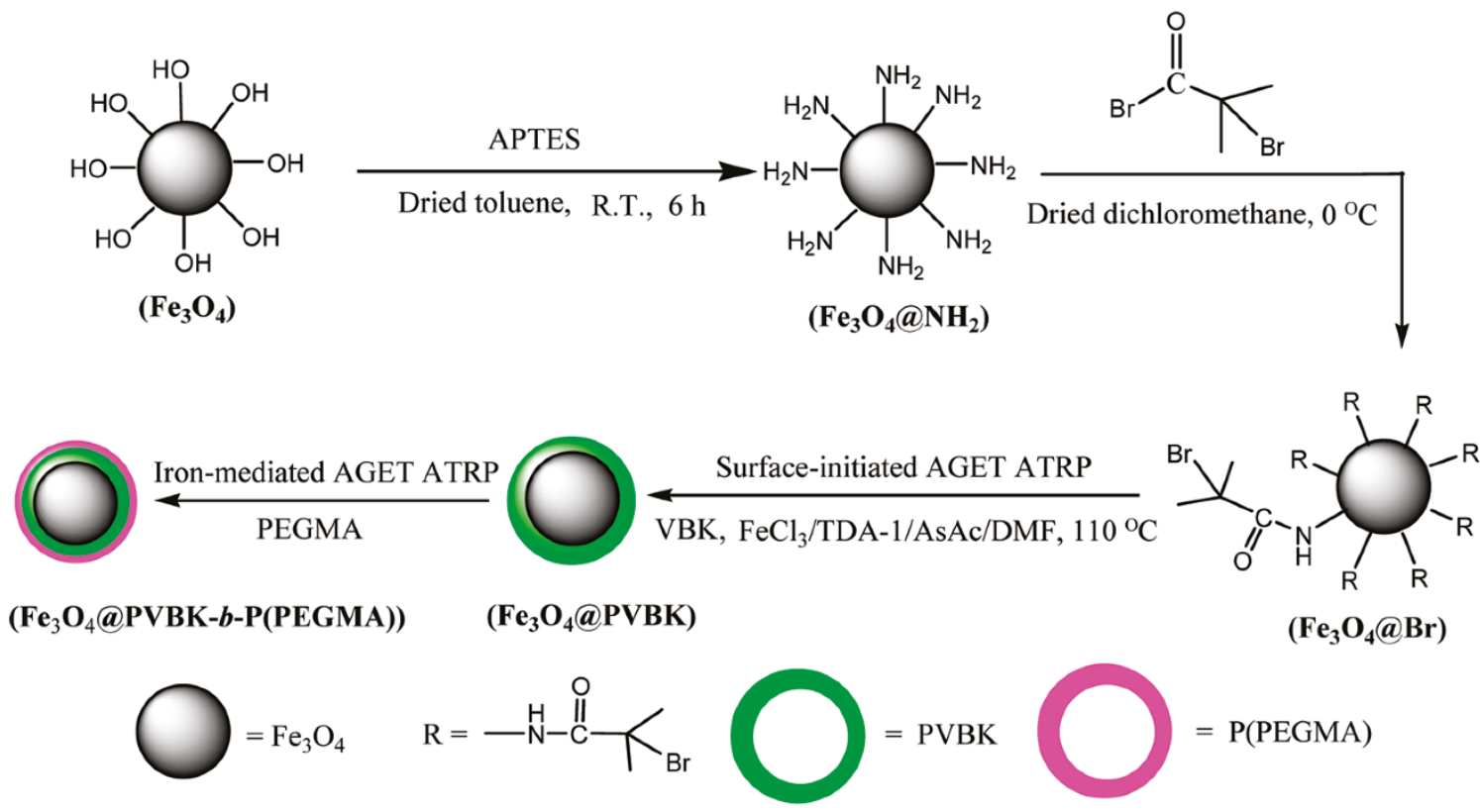

Figure 5. Synthetic route for the preparation of fluorescent/magnetic nanoparticles via iron-catalyzed ATRP [133]. Reprinted with permission from American Chemical Society, Copyright 2011.

Received core-shell nanostructures have potential use especially in in vitro and in vivo bioimaging and biological labelling [133]. Iron-mediated ATRP was used to graft PPEGMA $475-c o-P t B A$ from brominated MIONPs providing high stable nanoparticles in an aqueous medium, not recognized by macrophages, with immunogenic characteristics due to PPEGMA segment (Figure 6a). Hybrid material included carboxyl groups derived from acidic hydrolyze of tertiary butyl group of tert-butyl acrylate 
( $t$ BA) blocks, thus forming stable ester linkage between benzo[a]phenoxazine dyes-responsible for $\mathrm{pH}$-activatable NIR fluorescence features (Figure 6b). Prepared hybrid material showed negligible fluorescence above pH 7.0, while below pH 6.0 the fluorescence was significantly enhanced and discernible colour change was observed. This is desired due to the acidosis-tumour microenvironment indicator, which enables to improve tumour to normal tissue signal ratio ( $\mathrm{T} / \mathrm{N}$ ratio) in tumour imaging and hence is an attractive hallmark for tumour imaging. Moreover, multifunctional NPs facilitated the fluorescence enhancement in tumor cells (4T1 murine breast cancer cells and 293T human embryo kidney cells) under acidic conditions, receiving a satisfactory $\mathrm{T} / \mathrm{N}$ ratio [135].
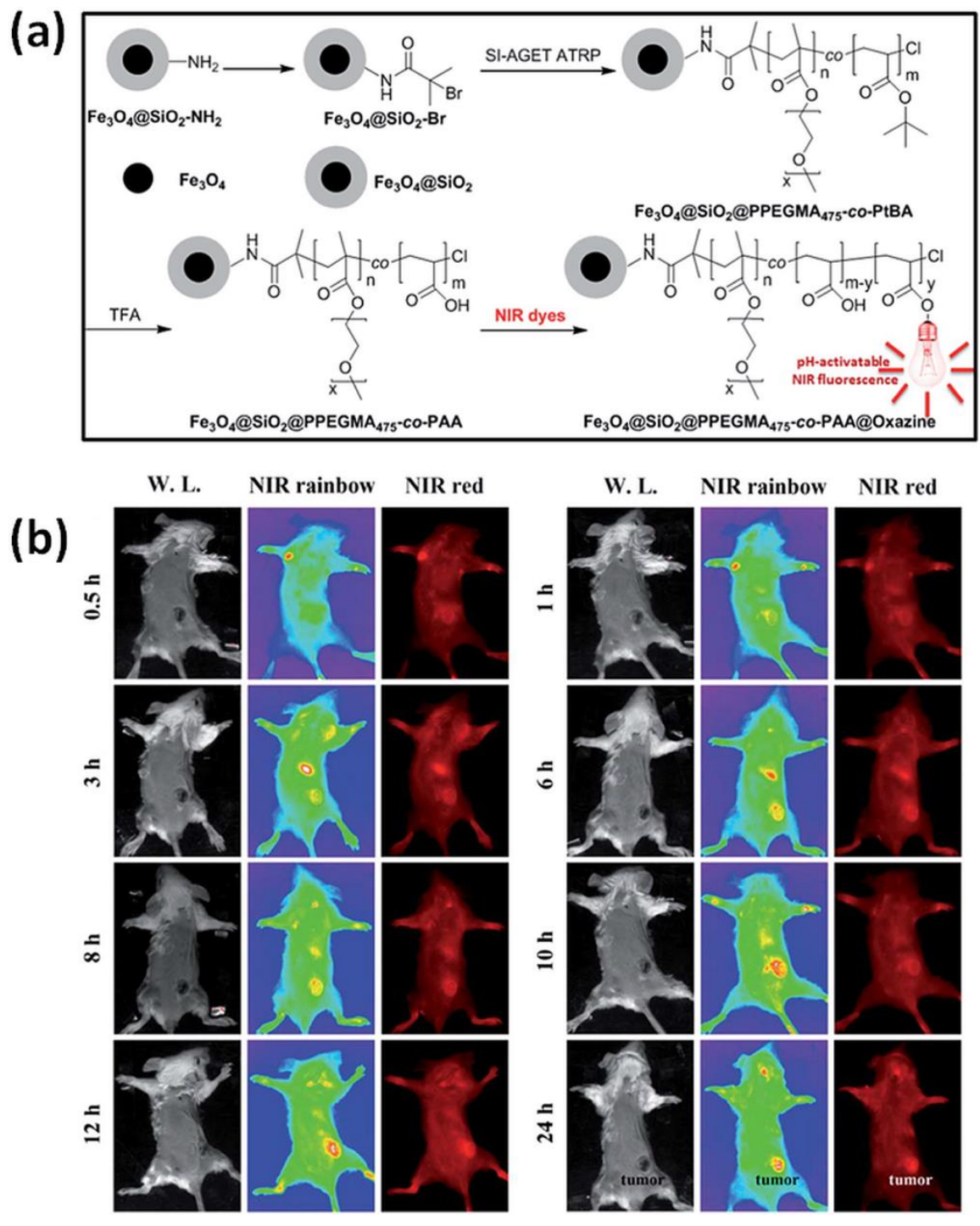

Figure 6. (a) Synthetic route for the preparation of MNPs characterized by bifunctional properties i.e., NIR fluorescence and magnetism by iron-mediated SI-AGET ATRP, subsequently modified by $\mathrm{pH}$-activatable benzo[ $a$ ]phenoxazine derivatives; (b) In vivo NIR fluorescence images of prepared hybrid material in 4T1 tumor-bearing mouse at indicated times after intravenous administration [135]. Reprinted with permission from Royal Society of Chemistry, Copyright 2015.

Nanoparticles-based hybrid materials were also received by modification of silica nanoparticles $\left(\mathrm{SiO}_{2}\right)$ with methyl methacrylate (MMA) and PEGMA 300 by surface-initiated AGET ATRP using iron(III) chloride/triphenylphosphine $\left(\mathrm{FeCl}_{3} / \mathrm{PPh}_{3}\right)$ as a catalyst complex and AsAc as a reducing agent, receiving precisely defined product proved by narrow MWD of grafted polymer chains [139]. Another silica-based substrate modified by $\mathrm{FeCl}_{3} / \mathrm{IDA}$ (iminodiacetic acid)/AsA-mediated ATRP 
was silica gel. Prepared high oil-absorption resins of copolymer composed of MMA and $n$-butyl methacrylate ( $n \mathrm{BMA})$ grafted from silica material demonstrated good heat-resistant quality, good oil absorbency, oil retention, and regeneration properties-promising features for an efficient oil-absorption material [134]. The synthetic nanomaterials, such as carbon nanotubes (CNTs) [136] and synthetic rubber polystyrene- $b$-poly(ethylene-co-1-butene)- $b$-polystyrene (SEBS) [140] were enhanced by modification via AGET ATRP with AsAc as a regenerator of catalyst complex $\mathrm{Fe}^{\mathrm{III}} \mathrm{Cl}_{3} \cdot 6 \mathrm{H}_{2} \mathrm{O} /$ tris(3,6-dioxaheptyl)amine (TDA-1), $\mathrm{Fe}^{\mathrm{III}} \mathrm{Cl}_{3} \cdot 6 \mathrm{H}_{2} \mathrm{O} / \mathrm{TDA}-1$ or $\mathrm{PPh}_{3}$, respectively. Over many advantages such as special mechanical, physical and chemical properties, CNTs have some disadvantages, i.e., limited dissolution in solvents and dispersion in most polymers, which reduces their practical application. For this reason, a wide range of polymers, such as PSt, PMMA and PPEGMA were successfully grafted onto the CNTs surfaces using iron-catalyzed system, therefore improving their properties [136]. While, SEBS as a commercially important thermoplastic elastomer, widely used in plastics, coatings, and adhesives, was modified by incorporation of PSt, PMMA, and PtBA to improve its compatibility with other materials [140]. Iron(III)-mediated AGET ATRP catalyst systems, as a biocompatible and low toxic approach, were successfully applied for modification of naturally-derived surfaces of chitosan nanospheres (CTSNSs), providing additional environmentally-friendly aspects over the ecological substrate, for preparation of hybrid materials (Figure 7). Well-defined PMMA or amphiphilic PMMA- $b$-PPEGMA brushes were grafted from the CTSNSs to yield individual nanospheres composed of a chitosan core and a well-defined polymer layer [141].
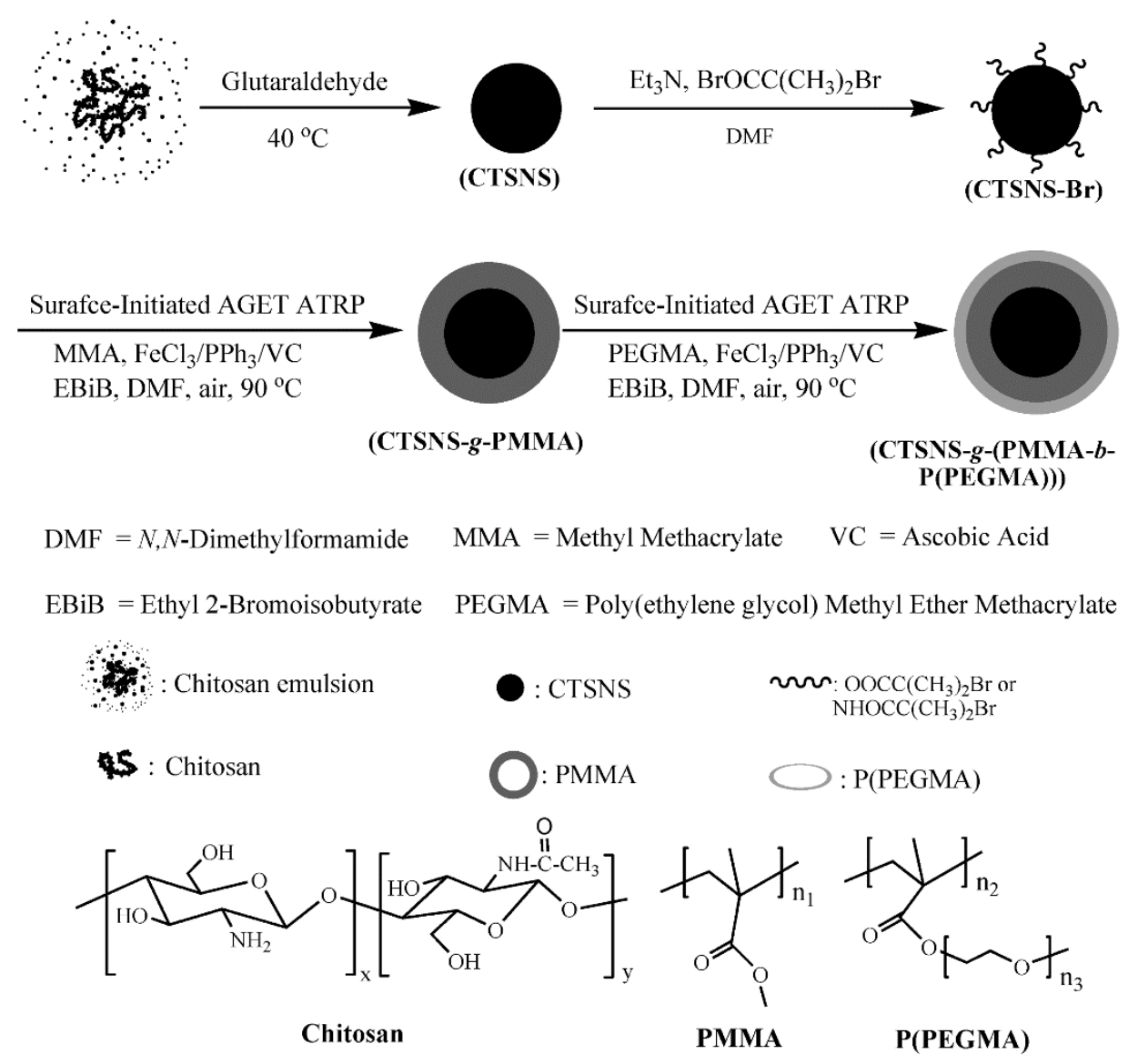

Figure 7. Modification of chitosan nanospheres (CTSNSs) by SI-AGET ATRP mediated by iron catalyst [141]. Reprinted with permission from American Chemical Society, Copyright 2009.

Nontoxic and ubiquitous iron-based complexes have proved perfect as a sustainable and environmentally friendly catalytic approach for controlled radical polymerizations in the preparation of functional materials e.g., copolymers, complex architectures, and hybrids with inorganic components 
in the form of grafting from the surface of substrates. The iron-catalyzed surface-initiated ATRP was successfully conducted on different substrates including silica, SEBS rubber, chitosan, and iron or silica oxide. Modification by ATRP improved the properties of modified substrates or provide completely new functionalities creating multifunctional materials.

\section{Future Prospects and Conclusions}

Transition metal complexes have become crucial catalysts in major industrial approaches. Among them, iron-based catalytic complexes stand out in particular due to the versatile directions of their applications. Iron with $N$ donor ligands complexes, even though apply chiefly as catalysts in homogeneous processes, are used also in other applications, including employed these complexes as photosensitizers or as precursors of catalysts immobilized on a solid support. Due to its advantages, e.g., low price, non-toxicity, readily availability) catalysts based on iron compounds have real future prospects and potential to replace some more expensive and polluting catalysts used currently in chemical processes. Medical application of [(TPMA)Fe ${ }^{\mathrm{II}}$ (diclofenac)] complex was also described, relies on an anti-proliferative effect on human breast cancer cells line (MDA-MB-231), providing promising insights into the development of non-platinum anti-cancer drugs with anti-inflammatory effects. Additionally, N-pentadentate iron(II) complexes of N4Py are excellent synthetic mimics of natural antibiotics used clinically to induce antitumor activity. Due to the high natural abundance and low cost of iron compounds, iron-based photocatalysts and photosensitizers belong to an important area of interest in photochemistry as alternatives of photofunctional complexes based currently on rare or heavy metals. Light-driven applications of iron NHC complexes are a subject of much research and the development of efficient iron-based dye-sensitized solar cells (DSSCs) is a great challenge for photovoltaics.

Focusing on sustainable and alternative catalytic systems for crucial industrial processes is of paramount importance to use an iron-catalyst for controlled radical polymerization techniques. This solution is characterized by low toxicity, and is thus eco-friendly and cost-effective in received polymers topology. Therefore, substitution of usually used cooper by iron in catalytic complex open new opportunities for solutions characterized by low toxicity, and thus environmental friendliness, low cost and abundance, hence the use of the iron-based catalyst enables further development of polymers with specialized applications obtained in ATRP approach. Undoubtedly, a challenge in this field is a combination of synthesis of organic-inorganic hybrid materials with simultaneous usage of iron oxide nanoparticles as catalytic complex and inorganic compounds in the prepared hybrid material. Moreover, the use of iron in ATRP synthesis is a step forward to receive fully-biocompatible synthesis. Iron-mediated low ppm ATRP with external control reduces the use of metal-based catalysts and an additional chemical reducing agent from the reaction setup. In this field photoinduced ATRP mediated by iron catalysts is recently extensively developing, aiming to significant reduction of catalyst loading until its complete removal to receive metal-free ATRP approaches.

Author Contributions: Conceptualization, P.C.; data curation, P.C. and I.Z.; visualization, K.R.-C., T.P., I.Z., P.B. and K.S.; writing—original draft preparation, K.R.-C., T.P., I.Z., P.B., K.S., A.S. and P.C.; writing-review \& editing, K.R.-C., T.P., I.Z., P.B., A.S. and P.C.; supervision, P.C.; project administration, P.C.; funding acquisition, P.C. and A.S. All authors have read and agreed to the published version of the manuscript.

Funding: This research received no external funding.

Acknowledgments: Financial support from UPB.CF.20.001.01 and BK/RDKN/2020/01 is gratefully acknowledged. P.C. acknowledges the Minister of Science and Higher Education scholarship for outstanding young scientists (0001/E-363/STYP/13/2018).

Conflicts of Interest: The authors declare no conflict of interest. 


\section{Abbreviations}

\begin{tabular}{|c|c|}
\hline $6-\mathrm{Me}_{2}-\mathrm{BPBP}$ & $(R, R)-1,1^{\prime}$-bis(6-methyl-2-pyridinylmethyl)-2,2'-bipyrrolidine) \\
\hline$n \mathrm{BA}$ & $n$-butyl acrylate \\
\hline$n$ BMA & $n$-butyl methacrylate \\
\hline ВPBP & 1,1'-bis(pyridin-2-ylmethyl)-2,2'-bipyrrolidine \\
\hline BPMCN & $N, N^{\prime}$-bis(2-pyridylmethyl)- $N, N^{\prime}$-dimethyl-trans-1,2-diaminocyclohexane \\
\hline BPMEN & $N^{1}, N^{2}$-dimethyl- $N^{1}, N^{2}$-bis(2-pyridylmethyl)ethane-1,2-diamine \\
\hline Bpy & $2,2^{\prime}$-bipyridine \\
\hline BPyA & 1-(bis(2-methylpyridyl)amino)-2-methyl-2-propanoate \\
\hline CNC & 2,6-bis-[3-(2,6-diisopropylphenyl)-imidazol-2-ylidene]pyridine \\
\hline CNF & carbon nanofiber \\
\hline CNT & carbon nanotube \\
\hline $\mathrm{CO}_{2} \mathrm{RR}$ & carbon dioxide reduction \\
\hline $\mathrm{Cp}$ & cyclopentadienyl \\
\hline $\mathrm{CPN}$ & 2-chloropropionitrile \\
\hline $\mathrm{CPP}$ & cell-penetrating peptide \\
\hline CTSNSs & surfaces of chitosan nanospheres \\
\hline DEGA & di(ethylene glycol) ethyl ether acrylate \\
\hline DFMA & dodecafluoroheptyl methacrylate \\
\hline DFT & density functional theory \\
\hline DMF & $N, N$-dimethylformamide \\
\hline DSSC & dye sensitized solar cell \\
\hline $\mathrm{Fe}_{3} \mathrm{O}_{4} @ \mathrm{SiO}_{2}-\mathrm{Br}$ & brominated silica-coated magnetic iron oxide nanoparticles \\
\hline HER & hydrogen evolution \\
\hline $\mathrm{H}_{2}$ pmen & $N, N^{\prime}$-bis(2-pyridylmethyl)ethylenediamine \\
\hline HTC & hydrothermal carbonization \\
\hline IDA & iminodiacetic acid \\
\hline IDipp & 1,3-bis(2,6-diisopropylphenyl)imidazol-2-ylidene \\
\hline IL & ionic liquid \\
\hline $\mathrm{LN}_{4} \mathrm{Me}_{2}$ & $N, N^{\prime}$-dimethyl-2,11-diaza[3.3](2,6)pyridinophane \\
\hline LNP & large nanoparticle \\
\hline$m \mathrm{CPBA}$ & $m$-chloroperoxybenzoic acid \\
\hline MIONPs & magnetic iron oxide nanoparticles \\
\hline $\mathrm{Me}_{3} \mathrm{TACN}$ & 1,4,7-trimethyltriazacyclononane, \\
\hline 6-Me $-\mathrm{MPMA}_{3}$ & tris(6-methyl-2-pyridylmethyl)amine \\
\hline 6-Me $\mathrm{Me}_{2}$-iso-BPMEN & $N^{1}, N^{1}$-dimethyl- $N^{2}, N^{2}$-bis(6-methyl-2-pyridylmethyl)ethane-1,2-diamine \\
\hline 6-Me $-\mathrm{MPMEN}_{2}$ & $N^{1}, N^{2}$-dimethyl- $N^{1}, N^{2}$-bis(6-methyl-2-pyridylmethyl)ethane-1,2-diamine \\
\hline $\mathrm{MePy}_{2} \mathrm{TACN}$ & $N$-methyl-N,N-bis(2-picolyl)-1,4,7-triazacyclononane \\
\hline $\mathrm{Me}_{2}$ PyTACN & 1,4-dimethyl-7-(2-pyridylmethyl)-1,4,7-triazacyclononane \\
\hline Me,MePyTACN & 1-(6-methyl-2-pyridylmethyl)-4,7-dimethyl-1,4,7-triazacyclononane \\
\hline MMA & methyl methacrylate \\
\hline MOF & metal organic framework \\
\hline MRI & magnetic resonance imaging \\
\hline MWCNTs-Br & brominated multiwall carbon nanotubes \\
\hline MWD & molecular weight distribution \\
\hline N4Py & $N, N$-bis(2-pyridylmethyl)- $N$-bis(2-pyridyl)methyl-amine) \\
\hline $\mathrm{NCCN}$ & bis(pyridylimidazol-2-ylidene)methane \\
\hline NHC & $N$-heterocyclic carbene \\
\hline NP & nanoparticle \\
\hline OER & oxygen evolution \\
\hline ORR & oxygen reduction reaction \\
\hline PBiBEM & poly[2-(2- bromoisobutyryloxy)ethyl methacrylate] \\
\hline $\mathrm{P} n \mathrm{BA}$ & poly $(n$-butyl acrylate $)$ \\
\hline PnBMA & poly(n-butyl methacrylate) \\
\hline
\end{tabular}




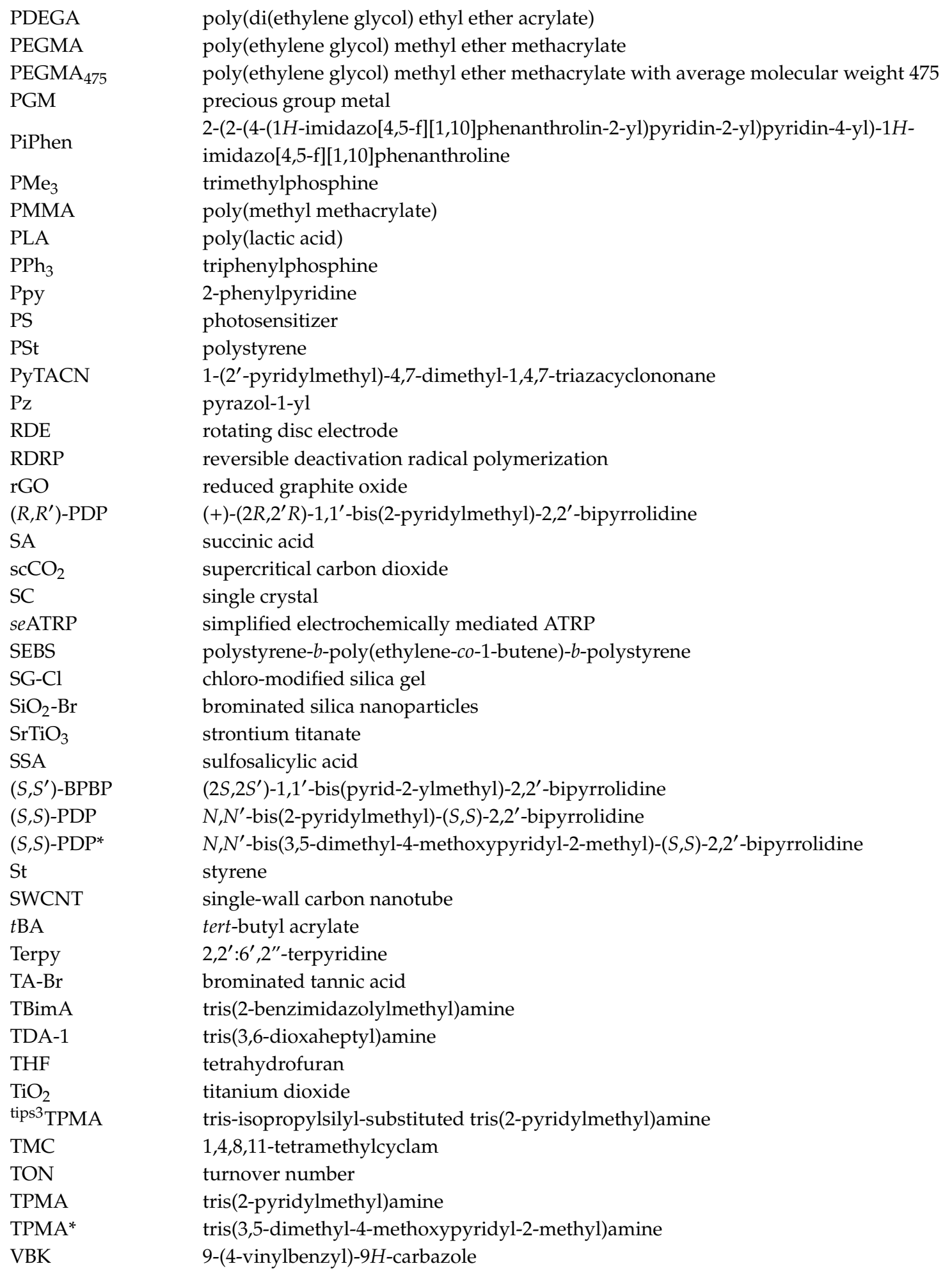

\section{References}

1. Chen, K.; Costas, M.; Kim, J.H.; Tipton, A.K.; Que, L. Olefin cis-dihydroxylation versus epoxidation by non-heme iron catalysts: Two faces of an Fe $\mathrm{III}_{-} \mathrm{OOH}$ coin. J. Am. Chem. Soc. 2002, 124, 3026-3035. [CrossRef] [PubMed]

2. Zima, A.M.; Lyakin, O.Y.; Bryliakov, K.P.; Talsi, E.P. On the nature of the active intermediates in iron-catalyzed oxidation of cycloalkanes with hydrogen peroxide and peracids. Mol. Catal. 2018, 455, 6-13. [CrossRef] 
3. Clemente-Tejeda, D.; Bermejo, F.A. Oxidation of alkenes with non-heme iron complexes: Suitability as an organic synthetic method. Tetrahedron 2014, 70, 9381-9386. [CrossRef]

4. Borrell, M.; Costas, M. Greening oxidation catalysis: Iron catalyzed alkene syn-dihydroxylation with aqueous hydrogen peroxide in green solvents. ACS Sustain. Chem. Eng. 2018, 6, 8410-8416. [CrossRef]

5. Lyakin, O.Y.; Zima, A.M.; Samsonenko, D.G.; Bryliakov, K.P.; Talsi, E.P. EPR spectroscopic detection of the elusive $\mathrm{Fe}-\mathrm{V}=\mathrm{O}$ intermediates in selective catalytic oxofunctionalizations of hydrocarbons mediated by biomimetic ferric complexes. ACS Catal. 2015, 5, 2702-2707. [CrossRef]

6. Oloo, W.N.; Meier, K.K.; Wang, Y.; Shaik, S.; Munck, E.; Que, L. Identification of a low-spin acylperoxoiron(III) intermediate in bio-inspired non-heme iron-catalysed oxidations. Nat. Commun. 2014, 5, 1-9. [CrossRef]

7. Morris, L.S.; Girouard, M.P.; Everhart, M.H.; McClain, W.E.; van Paridon, J.A.; Pike, R.D.; Goh, C. Epoxidation of alkenes bearing a carboxylic acid group by iron complexes of the tetradentate ligand $N, N^{\prime}$-dimethyl-N,N'-bis (2-pyridylmethyl)-1,2-diaminoethane and its derivatives. Inorg. Chim. Acta 2014, 413, 149-159. [CrossRef]

8. Kuck, J.W.; Raba, A.; Markovits, I.I.E.; Cokoja, M.; Kuhn, F.E. Epoxidation of olefins catalyzed by a molecular iron $N$-heterocyclic carbene complex: Influence of reaction parameters on the catalytic activity. ChemCatChem 2014, 6, 1882-1886. [CrossRef]

9. Jasinski, R. A new fuel cell cathode catalyst. Nature 1964, 201, 1212-1213. [CrossRef]

10. Gu, L.; Chu, Y.; Du, H.M.; Zhang, Y.; Zhao, J.S.; Xie, Y. Supramolecular iron complex formed between nitrogen riched phenanthroline derivative and iron with improved oxygen reduction activity in alkaline electrolyte. Front. Chem. 2019, 7, 1-12. [CrossRef] [PubMed]

11. Ao, X.; Zhang, W.; Li, Z.; Li, J.G.; Soule, L.; Huang, X.; Chiang, W.H.; Chen, H.M.; Wang, C.; Liu, M.; et al. Markedly enhanced oxygen reduction activity of single-atom Fe catalysts via integration with Fe nanoclusters. ACS Nano 2019, 13, 11853-11862. [CrossRef] [PubMed]

12. Jiang, W.J.; Gu, L.; Li, L.; Zhang, Y.; Zhang, X.; Zhang, L.J.; Wang, J.Q.; Hu, J.S.; Wei, Z.D.; Wan, L.J. Understanding the high activity of Fe-N-C electrocatalysts in oxygen reduction: $\mathrm{Fe} / \mathrm{Fe}_{3} \mathrm{C}$ nanoparticles boost the activity of Fe-N-x. J. Am. Chem. Soc. 2016, 138, 3570-3578. [CrossRef] [PubMed]

13. Shui, J.-L.; Karan, N.K.; Balasubramanian, M.; Li, S.-Y.; Liu, D.-J. Fe/N/C composite in $\mathrm{Li}_{-} \mathrm{O}_{2}$ battery: Studies of catalytic structure and activity toward oxygen evolution reaction. J. Am. Chem. Soc. 2012, 134, 16654-16661. [CrossRef] [PubMed]

14. Dhara, B.; Sappati, S.; Singh, S.K.; Kurungot, S.; Ghosh, P.; Ballav, N. Coordination polymers of Fe(III) and $\mathrm{Al}(\mathrm{III})$ ions with TCA ligand: Distinctive fluorescence, $\mathrm{CO}_{2}$ uptake, redox-activity and oxygen evolution reaction. Dalton Trans. 2016, 45, 6901-6908. [CrossRef] [PubMed]

15. Rana, A.; Mondal, B.; Sen, P.; Dey, S.; Dey, A. Activating Fe(I) porphyrins for the hydrogen evolution reaction using second-sphere proton transfer residues. Inorg. Chem. 2017, 56, 1783-1793. [CrossRef] [PubMed]

16. Zhang, Y.-Q.; Liao, R.-Z. Reaction mechanism of hydrogen evolution catalysed by Co and Fe complexes containing a tetra-dentate phosphine ligand-A DFT study. Phys. Chem. Chem. Phys. 2017, 19, 32589-32596. [CrossRef] [PubMed]

17. Zee, D.Z.; Nippe, M.; King, A.E.; Chang, C.J.; Long, J.R. Tuning second coordination sphere interactions in polypyridyl iron complexes to achieve selective electrocatalytic reduction of carbon dioxide to carbon monoxide. Inorg. Chem. 2020, 59, 5206-5217. [CrossRef]

18. Liu, Y.; You, T.; Wang, H.-X.; Tang, Z.; Zhou, C.-Y.; Che, C.-M. Iron- and cobalt-catalyzed C(sp3)-H bond functionalization reactions and their application in organic synthesis. Chem. Soc. Rev. 2020, 49, 5310-5358. [CrossRef]

19. Casadevall, C.; Bucci, A.; Costas, M.; Lloret-Fillol, J. Chapter Four-Water oxidation catalysis with well-defined molecular iron complexes. In Advances in Inorganic Chemistry; van Eldik, R., Hubbard, C.D., Eds.; Academic Press: Cambridge, MA, USA, 2019; Volume 74, pp. 151-196.

20. Pereira, M.M.; Dias, L.D.; Calvete, M.J.F. Metalloporphyrins: Bioinspired oxidation catalysts. ACS Catal. 2018, 8, 10784-10808. [CrossRef]

21. Calvete, M.J.F.; Piñeiro, M.; Dias, L.D.; Pereira, M.M. Hydrogen peroxide and metalloporphyrins in oxidation catalysis: Old dogs with some new tricks. Chem CatChem 2018, 10, 3615-3635. [CrossRef]

22. Dadashi-Silab, S.; Matyjaszewski, K. Iron catalysts in atom transfer radical polymerization. Molecules 2020, 25, 1648. [CrossRef] [PubMed] 
23. Poli, R.; Allan, L.E.N.; Shaver, M.P. Iron-mediated reversible deactivation controlled radical polymerization. Prog. Polym. Sci. 2014, 39, 1827-1845. [CrossRef]

24. Zang, Y.; Kim, J.; Dong, Y.H.; Wilkinson, E.C.; Appelman, E.H.; Que, L. Models for nonheme iron intermediates: Structural basis for tuning the spin states of Fe(TPA) complexes. J. Am. Chem. Soc. 1997, 119, 4197-4205. [CrossRef]

25. Kim, J.; Kim, C.; Harrison, R.G.; Wilkinson, E.C.; Que, L. Fe(TPA)-catalyzed alkane hydroxylation can be a metal-based oxidation. J. Mol. Catal. A Chem. 1997, 117, 83-89. [CrossRef]

26. Kaizer, J.; Klinker, E.J.; Oh, N.Y.; Rohde, J.U.; Song, W.J.; Stubna, A.; Kim, J.; Munck, E.; Nam, W.; Que, L. Nonheme (FeO)-O-IV complexes that can oxidize the $\mathrm{C}-\mathrm{H}$ bonds of cyclohexane at room temperature. J. Am. Chem. Soc. 2004, 126, 472-473. [CrossRef]

27. Costas, M.; Mehn, M.P.; Jensen, M.P.; Que, L. Dioxygen activation at mononuclear nonheme iron active sites: Enzymes, models, and intermediates. Chem. Rev. 2004, 104, 939-986. [CrossRef]

28. Kerber, W.D.; Perez, K.A.; Ren, C.Q.; Siegler, M.A. Speciation of ferric phenoxide intermediates during the reduction of iron(III)-mu-Oxo dimers by hydroquinone. Inorg. Chem. 2014, 53, 11507-11516. [CrossRef]

29. Ansari, A.; Rajaraman, G. ortho-Hydroxylation of aromatic acids by a non-heme $\mathrm{Fe}-\mathrm{V}=\mathrm{O}$ species: How important is the ligand design? Phys. Chem. Chem. Phys. 2014, 16, 14601-14613. [CrossRef]

30. Nam, W. Synthetic mononuclear nonheme iron-oxygen intermediates. Acc. Chem. Res. 2015, 48, 2415-2423. [CrossRef]

31. Chakraborty, B.; Jana, R.D.; Singh, R.; Paria, S.; Paine, T.K. Reductive activation of $\mathrm{O}_{2}$ by non-heme Iron(II) benzilate complexes of $\mathrm{N}_{4}$ ligands: Effect of ligand topology on the reactivity of $\mathrm{O}_{2}$-derived oxidant. Inorg. Chem. 2017, 56, 359-371. [CrossRef]

32. Porter, D.; Poon, B.M.L.; Rutledge, P.J. Iron complexes of tetramine ligands catalyse allylic hydroxyamination via a nitroso-ene mechanism. Beilstein J. Org. Chem. 2015, 11, 2549-2556. [CrossRef] [PubMed]

33. Lakshman, T.R.; Chatterjee, S.; Chakraborty, B.; Paine, T.K. Substrate-dependent aromatic ring fission of catechol and 2-aminophenol with $\mathrm{O}_{2}$ catalyzed by a nonheme iron complex of a tripodal $\mathrm{N}_{4}$ ligand. Dalton Trans. 2016, 45, 8835-8844. [CrossRef]

34. Chakraborty, B.; Bhunya, S.; Paul, A.; Paine, T.K. Reactivity of biomimetic iron(II)-2-aminophenolate complexes toward dioxygen: Mechanistic investigations on the oxidative C-C bond cleavage of substituted 2-aminophenols. Inorg. Chem. 2014, 53, 4899-4912. [CrossRef]

35. Lakk-Bogath, D.; Speier, G.; Kaizer, J. Oxoiron(IV)-mediated Baeyer-Villiger oxidation of cyclohexanones generated by dioxygen with co-oxidation of aldehydes. New J. Chem. 2015, 39, 8245-8248. [CrossRef]

36. Ayad, M.; Gebbink, R.; Le Mest, Y.; Schollhammer, P.; Le Poul, N.; Petillon, F.Y.; Mandon, D. Mononuclear iron(II) complexes containing a tripodal and macrocyclic nitrogen ligand: Synthesis, reactivity and application in cyclohexane oxidation catalysis. Dalton Trans. 2018, 47, 15596-15612. [CrossRef] [PubMed]

37. McArthur, S.; Baird, M.C. Oxyfunctionalization of polystyrene by hydrogen peroxide using non-heme iron catalysts. Eur. Polym. J. 2014, 55, 170-178. [CrossRef]

38. Parent, A.R.; Nakazono, T.; Lin, S.; Utsunomiya, S.; Sakai, K. Mechanism of water oxidation by non-heme iron catalysts when driven with sodium periodate. Dalton Trans. 2014, 43, 12501-12513. [CrossRef]

39. Zhang, B.B.; Li, F.; Yu, F.S.; Cui, H.H.; Zhou, X.; Li, H.; Wang, Y.; Sun, L.C. Homogeneous oxidation of water by iron complexes with macrocyclic ligands. Chem. Asian J. 2014, 9, 1515-1518. [CrossRef]

40. Acuna-Pares, F.; Costas, M.; Luis, J.M.; Lloret-Fillol, J. Theoretical study of the water oxidation mechanism with non-heme $\mathrm{Fe}\left(\right.$ Pytacn) Iron complexes. Evidence that the $\mathrm{Fe}^{\mathrm{IV}}(\mathrm{O})($ Pytacn) species cannot react with the water molecule to form the O-O bond. Inorg. Chem. 2014, 53, 5474-5485. [CrossRef]

41. Hon, Y.H.; Jung, J.; Awa, T.N.; Sharma, N.; Lee, Y.M.; Nam, W.; Fukuzumi, S. Photodriven oxidation of water by plastoquinone analogs with a nonheme iron catalyst. J. Am. Chem. Soc. 2019, 141, 6748-6754.

42. Sun, X.P.; Wei, R.J.; Yao, Z.S.; Tao, J. Solvent effects on the structural packing and spin-crossover properties of a mononuclear iron(II) complex. Cryst. Growth Des. 2018, 18, 6853-6862. [CrossRef]

43. Zheng, C.Y.; Xu, J.P.; Wang, F.; Tao, J.; Li, D.F. Spin crossover and reversible single-crystal to single-crystal transformation behaviour in two cyanide-bridged mixed-valence $\left\{\mathrm{Fe}^{\mathrm{III}}{ }_{2} \mathrm{Fe}_{2}{ }_{2}\right\}$ clusters. Dalton Trans. 2016, 45, 17254-17263. [CrossRef]

44. Perera, I.R.; Daeneke, T.; Makuta, S.; Yu, Z.; Tachibana, Y.; Mishra, A.; Bauerle, P.; Ohlin, C.A.; Bach, U.; Spiccia, L. Application of the tris(acetylacetonato)iron(III)/(II) redox couple in p-type dye-sensitized solar cells. Angew. Chem. Int. Ed. 2015, 54, 3758-3762. [CrossRef] 
45. Popov, I.A.; Davis, B.L.; Mukundan, R.; Batista, E.R.; Yang, P. Catalyst-inspired charge carriers for high energy density redox flow batteries. Front. Phys. 2019, 6, 1-10. [CrossRef]

46. Lakshman, T.R.; Deb, J.; Ghosh, I.; Sarkar, S.; Paine, T.K. Combining anti-inflammatory and anti-proliferative activities in ternary metal-NSAID complexes of a polypyridylamine ligand. Inorg. Chim. Acta 2019, 486, 663-668. [CrossRef]

47. Li, Q.; van der Wijst, M.G.P.; Kazernier, H.G.; Rots, M.G.; Roelfes, G. Efficient nuclear DNA cleavage in human cancer cells by synthetic bleomycin mimics. ACS Chem. Biol. 2014, 9, 1044-1051. [CrossRef]

48. Gonzalez-Bartulos, M.; Aceves-Luquero, C.; Qualai, J.; Cusso, O.; Martinez, M.A.; de Mattos, S.F.; Menendez, J.A.; Villalonga, P.; Costas, M.; Ribas, X.; et al. Pro-oxidant activity of amine-pyridine-based iron complexes efficiently kills cancer and cancer stem-like cells. PLoS ONE 2015, 10, e0137800. [CrossRef]

49. Soler, M.; Gonzalez-Bartulos, M.; Figueras, E.; Massaguer, A.; Feliu, L.; Planas, M.; Ribas, X.; Costas, M. Delivering aminopyridine ligands into cancer cells through conjugation to the cell-penetrating peptide BP16. Org. Biomol. Chem. 2016, 14, 4061-4070. [CrossRef]

50. Raba, A.; Cokoja, M.; Herrmann, W.A.; Kuhn, F.E. Catalytic hydroxylation of benzene and toluene by an iron complex bearing a chelating di-pyridyl-di-NHC ligand. Chem. Commun. 2014, 50, 11454-11457. [CrossRef]

51. Karaca, O.; Anneser, M.R.; Kuck, J.W.; Lindhorst, A.C.; Cokoja, M.; Kuhn, F.E. Iron(II) N-heterocyclic carbene complexes in catalytic one-pot Wittig reactions: Mechanistic insights. J. Catal. 2016, 344, 213-220. [CrossRef]

52. Pradeep, T.; Velusamy, M.; Mayilmurugan, R. Novel iron(II)- $N$-heterocyclic carbene catalysts for efficient transfer hydrogenations under mild condition. Mol. Catal 2018, 459, 71-77. [CrossRef]

53. Chen, M.Z.; Sun, H.M.; Li, W.F.; Wang, Z.G.; Shen, Q.; Zhang, Y. Synthesis, structure of functionalized $\mathrm{N}$-heterocyclic carbene complexes of $\mathrm{Fe}(\mathrm{II})$ and their catalytic activity for ring-opening polymerization of epsilon-caprolactone. J. Organomet. Chem. 2006, 691, 2489-2494. [CrossRef]

54. Wang, Y.; Sun, H.; Tao, X.; Shen, Q.; Zhang, Y. Enolate chelating N-heterocyclic carbene complexes of Fe(II): Synthesis, structure and their catalytic activity for ring-opening polymerization of epsilon-caprolactone. Chin. Sci. Bull. 2007, 52, 3193-3199. [CrossRef]

55. Manna, C.M.; Kaplan, H.Z.; Li, B.; Byers, J.A. High molecular weight poly(lactic acid) produced by an efficient iron catalyst bearing a bis(amidinato)- $N$-heterocyclic carbene ligand. Polyhedron 2014, 84, 160-167. [CrossRef]

56. Zimmer, P.; Muller, P.; Burkhardt, L.; Schepper, R.; Neuba, A.; Steube, J.; Dietrich, F.; Florke, U.; Mangold, S.; Gerhards, M.; et al. N-heterocyclic carbene complexes of iron as photosensitizers for light-induced water reduction. Eur. J. Inorg. Chem. 2017, 2017, 1504-1509. [CrossRef]

57. Pastore, M.; Duchanois, T.; Liu, L.; Monari, A.; Assfeld, X.; Haacke, S.; Gros, P.C. Interfacial charge separation and photovoltaic efficiency in Fe(II)-carbene sensitized solar cells. Phys. Chem. Chem. Phys. 2016, 18, 28069-28081. [CrossRef] [PubMed]

58. Vinagreiro, C.S.; Lopes, R.; Royo, B.; Da Silva, G.J.; Pereira, M.M. Synthesis of iron(II)-N-heterocyclic carbene complexes: Paving the way for a new class of antibiotics. Molecules 2020, 25, 2917. [CrossRef] [PubMed]

59. Matias, I.A.S.; Ribeiro, A.P.C.; Alegria, E.; Pombeiro, A.J.L.; Martins, L. C-scorpionate iron(II) complexes as highly selective catalysts for the hydrocarboxylation of cyclohexane. Inorg. Chim. Acta 2019, 489, 269-274. [CrossRef]

60. Ribeiro, A.P.C.; Martins, L.; Pombeiro, A.J.L. $\mathrm{N}_{2}$ O-Free single-pot conversion of cyclohexane to adipic acid catalysed by an iron(II) scorpionate complex. Green Chem. 2017, 19, 1499-1501. [CrossRef]

61. Ribeiro, A.P.C.; Martins, L.; Pombeiro, A.J.L. Carbon dioxide-to-methanol single-pot conversion using a C-scorpionate iron(II) catalyst. Green Chem. 2017, 19, 4811-4815. [CrossRef]

62. Mendes, M.; Ribeiro, A.P.C.; Alegria, E.C.B.A.; Martins, L.M.D.R.S.; Pombeiro, A.J.L. Liquid phase oxidation of xylenes catalyzed by the tripodal C-scorpionate iron(II) complex $\left[\mathrm{FeCl}_{2}\left\{\mathrm{k}^{3}-\mathrm{HC}(\mathrm{pz})_{3}\right\}\right]$. Polyhedron 2017, 125, 151-155. [CrossRef]

63. Ribeiro, A.P.C.; Martins, L.; Alegria, E.; Matias, I.A.S.; Duarte, T.A.G.; Pombeiro, A.J.L. Catalytic performance of $\mathrm{Fe}(\mathrm{II})$-scorpionate complexes towards cyclohexane oxidation in organic, ionic liquid and/or supercritical $\mathrm{CO}_{2}$ media: A comparative study. Catalysts 2017, 7, 230. [CrossRef]

64. Louie, J.; Grubbs, R.H. Highly active iron imidazolylidene catalysts for atom transfer radical polymerization. Chem. Commun. 2000, 16, 1479-1480. [CrossRef] 
65. Riener, K.; Haslinger, S.; Raba, A.; Hogerl, M.P.; Cokoja, M.; Herrmann, W.A.; Kuhn, F.E. Chemistry of iron $N$-heterocyclic carbene complexes: Syntheses, structures, reactivities, and catalytic applications. Chem. Rev. 2014, 114, 5215-5272. [CrossRef]

66. Charra, V.; de Fremont, P.; Braunstein, P. Multidentate N-heterocyclic carbene complexes of the 3d metals: Synthesis, structure, reactivity and catalysis. Coord. Chem. Rev. 2017, 341, 53-176. [CrossRef]

67. Johnson, C.; Albrecht, M. Piano-stool N-heterocyclic carbene iron complexes: Synthesis, reactivity and catalytic applications. Coord. Chem. Rev. 2017, 352, 1-14. [CrossRef]

68. Liang, Q.M.; Song, D.T. Iron N-heterocyclic carbene complexes in homogeneous catalysis. Chem. Soc. Rev. 2020, 49, 1209-1232. [CrossRef]

69. Lindh, L.; Chabera, P.; Rosemann, N.W.; Uhlig, J.; Warnmark, K.; Yartsev, A.; Sundstrom, V.; Persson, P. Photophysics and photochemistry of iron carbene complexes for solar energy conversion and photocatalysis. Catalysts 2020, 10, 315. [CrossRef]

70. Pettinari, C.; Pettinari, R.; Marchetti, F. Golden jubilee for scorpionates: Recent advances in organometallic chemistry and their role in catalysis. In Advances in Organometallic Chemistry; Perez, P.J., Ed.; Elsevier: Amsterdam, The Netherlands, 2016; Volume 65, pp. 175-260.

71. Pettinari, C. Scorpionate compounds. Eur. J. Inorg. Chem. 2016, 2016, 2209-2211. [CrossRef]

72. Martins, L.; Pombeiro, A.J.L. Tris(pyrazol-1-yl)methane metal complexes for catalytic mild oxidative functionalizations of alkanes, alkenes and ketones. Coord. Chem. Rev. 2014, 265, 74-88. [CrossRef]

73. Martins, L. C-scorpionate complexes: Ever young catalytic tools. Coord. Chem. Rev. 2019, 396, 89-102. [CrossRef]

74. Dalle, K.E.; Warnan, J.; Leung, J.J.; Reuillard, B.; Karmel, I.S.; Reisner, E. Electro- and solar-driven fuel synthesis with first row transition metal complexes. Chem. Rev. 2019, 119, 2752-2875. [CrossRef]

75. Haag, W.O.; Whitehurst, D.D. Insoluble resin-metal compound complex prepared by contacting weak base ion exchange resin with solution of metal-ligand. U.S. Patent 4111856A, 29 August 1974.

76. Maurin, A.; Robert, M. Noncovalent immobilization of a molecular iron-based electrocatalyst on carbon electrodes for selective, efficient $\mathrm{CO}_{2}$-to-CO conversion in water. J. Am. Chem. Soc. 2016, 138, 2492-2495. [CrossRef]

77. Kumar, A.; Kumar, P.; Joshi, C.; Ponnada, S.; Pathak, A.K.; Ali, A.; Sreedhar, B.; Jain, S.L. A [Fe(bpy) $\left.]_{3}\right]^{2+}$ grafted graphitic carbon nitride hybrid for visible light assisted oxidative coupling of benzylamines under mild reaction conditions. Green Chem. 2016, 18, 2514-2521. [CrossRef]

78. Sobkowiak, A.; Szczepanik, A.; Narog, D.; Charczuk, M. Oxidation of limonene with dioxygen catalyzed by 2,2'-bipyridyl manganese(II) and iron(II) complexes supported on a bentonite carrier. Przem Chem. 2015, 94, 2006-2009.

79. Venegas, R.; Recio, F.J.; Riquelme, J.; Neira, K.; Marco, J.F.; Ponce, I.; Zagal, J.H.; Tasca, F. Biomimetic reduction of $\mathrm{O}_{2}$ in an acid medium on iron phthalocyanines axially coordinated to pyridine anchored on carbon nanotubes. J. Mater. Chem. A 2017, 5, 12054-12059. [CrossRef]

80. Hod, I.; Sampson, M.D.; Deria, P.; Kubiak, C.P.; Farha, O.K.; Hupp, J.T. Fe-Porphyrin-based metal-organic framework films as high-surface concentration, heterogeneous catalysts for electrochemical reduction of $\mathrm{CO}_{2}$. ACS Catal. 2015, 5, 6302-6309. [CrossRef]

81. Race, N.A.; Zhang, W.; Screen, M.E.; Barden, B.A.; McNamara, W.R. Iron polypyridyl catalysts assembled on metal oxide semiconductors for photocatalytic hydrogen generation. Chem. Commun. 2018, 54, 3290-3293. [CrossRef]

82. Hailu, S.L.; Nair, B.U.; Redi-Abshiro, M.; Aravindhan, R.; Diaz, I.; Tessema, M. Experimental and computational studies on zeolite-Y encapsulated iron(III) and nickel(II) complexes containing mixed-ligands of 2,2'-bipyridine and 1,10-phenanthroline. RSC Adv. 2015, 5, 88636-88645. [CrossRef]

83. Xue, H.; He, T.; Chabu, J.M.; Liu, J.J.; Wu, H.Q.; Zheng, J.; Tan, M.L.; Ma, J.; Shen, R.J.; Deng, L.; et al. Iron single clusters anchored on $\mathrm{N}$-doped porous carbon as superior trace-metal catalysts toward oxygen reduction. Adv. Mater. Interfaces 2018, 5, 1701345. [CrossRef]

84. Liu, L.; Zhao, X.; Li, R.; Su, H.; Zhang, H.; Liu, Q. Subnano amorphous Fe-based clusters with high mass activity for efficient electrocatalytic oxygen reduction reaction. ACS Appl. Mater. Interfaces 2019, 11, 41432-41439. [CrossRef] 
85. Jagadeesh, R.V.; Surkus, A.E.; Junge, H.; Pohl, M.M.; Radnik, J.; Rabeah, J.; Huan, H.M.; Schunemann, V.; Bruckner, A.; Beller, M. Nanoscale $\mathrm{Fe}_{2} \mathrm{O}_{3}$-based catalysts for selective hydrogenation of nitroarenes to anilines. Science 2013, 342, 1073-1076. [CrossRef]

86. Jagadeesh, R.V.; Natte, K.; Junge, H.; Beller, M. Nitrogen-doped graphene-activated iron-oxide-based nanocatalysts for selective transfer hydrogenation of nitroarenes. ACS Catal. 2015, 5, 1526-1529. [CrossRef]

87. Stemmler, T.; Surkus, A.E.; Pohl, M.M.; Junge, K.; Beller, M. Iron-catalyzed synthesis of secondary amines: On the way to green reductive aminations. Chemsuschem 2014, 7, 3012-3016. [CrossRef]

88. Natte, K.; Neumann, H.; Jagadeesh, R.V.; Beller, M. Convenient iron-catalyzed reductive aminations without hydrogen for selective synthesis of $N$-methylamines. Nat. Commun. 2017, 8, 1-9. [CrossRef]

89. Ryabchuk, P.; Junge, K.; Beller, M. Heterogeneous iron-catalyzed hydrogenation of nitroarenes under water-gas shift reaction conditions. Synth. Stuttg. 2018, 50, 4369-4376.

90. Jagadeesh, R.V.; Junge, H.; Beller, M. Green synthesis of nitriles using non-noble metal oxides-based nanocatalysts. Nat. Commun. 2014, 5, 1-8. [CrossRef]

91. Jagadeesh, R.V.; Junge, H.; Beller, M. “Nanorust"-catalyzed benign oxidation of amines for selective synthesis of nitriles. Chemsuschem 2015, 8, 92-96. [CrossRef]

92. Lee, H.; Kim, M.J.; Lim, T.; Sung, Y.E.; Kim, H.J.; Lee, H.N.; Kwon, O.J.; Cho, Y.H. A facile synthetic strategy for iron, aniline-based non-precious metal catalysts for polymer electrolyte membrane fuel cells. Sci. Rep. 2017, 7, 1-8. [CrossRef]

93. Li, J.C.; Yang, Z.Q.; Tang, D.M.; Zhang, L.; Hou, P.X.; Zhao, S.Y.; Liu, C.; Cheng, M.; Li, G.X.; Zhang, F.; et al. $\mathrm{N}$-doped carbon nanotubes containing a high concentration of single iron atoms for efficient oxygen reduction. NPG Asia Mater 2018, 10, e461. [CrossRef]

94. Li, Y.; Liu, T.; Yang, W.; Zhu, Z.; Zhai, Y.; Gu, W.; Zhu, C. Multiscale porous Fe-N-C networks as highly efficient catalysts for the oxygen reduction reaction. Nanoscale 2019, 11, 19506-195011. [CrossRef]

95. Boulatov, R.; Collman, J.P.; Shiryaeva, I.M.; Sunderland, C.J. Functional analogues of the dioxygen reduction site in cytochrome oxidase: Mechanistic aspects and possible effects of Cu-B. J. Am. Chem. Soc. 2002, 124, 11923-11935. [CrossRef]

96. Alt, H.; Binder, H.; Sandstede, G. Mechanism of the electrocatalytic reduction of oxygen on metal chelates. J. Catal. 1973, 28, 8-19. [CrossRef]

97. Jahnke, H.; Schönborn, M.; Zimmermann, G. Organic dyestuffs as catalysts for fuel cells. Topp. Curr. Chem. 1976, 61, 133-181.

98. Sa, Y.J.; Kim, J.H.; Joo, S.H. Recent progress in the identification of active sites in pyrolyzed Fe-N/C catalysts and insights into their role in oxygen reduction reaction. J. Electrochem. Sci. Te. 2017, 8, 169-182. [CrossRef]

99. Li, A.; Nicolae, S.A.; Qiao, M.; Preuss, K.; Szilágyi, P.A.; Moores, A.; Titirici, M.-M. Homogenous meets heterogenous and electro-catalysis: Iron-nitrogen molecular complexes within carbon materials for catalytic applications. Chem CatChem 2019, 11, 3602-3625. [CrossRef]

100. Shen, H.; Thomas, T.; Rasaki, S.A.; Saad, A.; Hu, C.; Wang, J.; Yag, M. Oxygen reduction reactions of Fe-N-C catalysts: Current status and the way forward. Electrochem. Energ. Rev. 2019, 2, 252-276. [CrossRef]

101. Wang, Y.C.; Lai, Y.J.; Song, L.; Zhou, Z.Y.; Liu, J.G.; Wang, Q.; Yang, X.D.; Chen, C.; Shi, W.; Zheng, Y.P.; et al. S-doping of an Fe/N/C ORR catalyst for polymer electrolyte membrane fuel cells with high power density. Angew. Chem. Int. Ed. 2015, 54, 9907-9910. [CrossRef]

102. Hu, S.; Wang, X. Ultrathin nanostructures: Smaller size with new phenomena. Chem. Soc. Rev. 2013, 42, 5577-5594. [CrossRef]

103. Chen, Y.J.; Ji, S.F.; Wang, Y.G.; Dong, J.C.; Chen, W.X.; Li, Z.; Shen, R.A.; Zheng, L.R.; Zhuang, Z.B.; Wang, D.S.; et al. Isolated single iron atoms anchored on $N$-doped porous carbon as an efficient electrocatalyst for the oxygen reduction reaction. Angew. Chem. Int. Ed. 2017, 56, 6937-6941. [CrossRef]

104. Chen, P.Z.; Zhou, T.P.; Xing, L.L.; Xu, K.; Tong, Y.; Xie, H.; Zhang, L.D.; Yan, W.S.; Chu, W.S.; Wu, C.Z.; et al. Atomically dispersed iron-nitrogen species as electrocatalysts for bifunctional oxygen evolution and reduction reactions. Angew. Chem. Int. Ed. 2017, 56, 610-614. [CrossRef] [PubMed]

105. Zhang, H.G.; Hwang, S.; Wang, M.Y.; Feng, Z.X.; Karakalos, S.; Luo, L.L.; Qiao, Z.; Xie, X.H.; Wang, C.M.; $\mathrm{Su}, \mathrm{D}$; et al. Single atomic iron catalysts for oxygen reduction in acidic media: Particle size control and thermal activation. J. Am. Chem. Soc. 2017, 139, 14143-14149. [CrossRef] [PubMed]

106. Peng, Y.; Lu, B.Z.; Chen, S.W. Carbon-supported single atom catalysts for electrochemical energy conversion and storage. Adv. Mater. 2018, 30, 1801995. [CrossRef] [PubMed] 
107. Chen, Y.J.; Ji, S.F.; Zhao, S.; Chen, W.X.; Dong, J.C.; Cheong, W.C.; Shen, R.A.; Wen, X.D.; Zheng, L.R.; Rykov, A.I.; et al. Enhanced oxygen reduction with single-atomic-site iron catalysts for a zinc-air battery and hydrogen-air fuel cell. Nat. Commun. 2018, 9, 1-12. [CrossRef] [PubMed]

108. Liu, Z.; Huang, Y.; Zhang, X.; Tu, X.; Wang, M.; Ma, L.; Wang, B.; He, J.; Ni, P.; Wei, H. Fabrication of cyclic brush copolymers with heterogeneous amphiphilic polymer brushes for controlled drug release. Macromolecules 2018, 51, 7672-7679. [CrossRef]

109. Zhao, L.; Zhang, Y.; Huang, L.B.; Liu, X.Z.; Zhang, Q.H.; He, C.; Wu, Z.Y.; Zhang, L.J.; Wu, J.P.; Yang, W.L.; et al. Cascade anchoring strategy for general mass production of high-loading single-atomic metal-nitrogen catalysts. Nat. Commun. 2019, 10,1-11. [CrossRef] [PubMed]

110. Ni, B.; Shi, Y.; Wang, X. The sub-nanometer scale as a new focus in nanoscience. Adv. Mater. 2018, 30, 1802031. [CrossRef]

111. Osmieri, L. Transition metal-nitrogen-carbon (M-N-C) catalysts for oxygen reduction reaction. Insights on synthesis and performance in polymer electrolyte fuel cells. ChemEngineering 2019, 3, 16. [CrossRef]

112. González-Cervantes, E.; Crisóstomo, A.A.; Gutiérrez-Alejandre, A.; Varela, A.S. Optimizing FeNC materials as electrocatalysts for the $\mathrm{CO}_{2}$ reduction reaction: Heat-treatment temperature, structure and performance correlations. ChemCatChem 2019, 11, 4854-4861. [CrossRef]

113. Wang, Y.; Wang, J.; Wei, D.; Li, M. A “MOF-protective-pyrolysis" strategy for the preparation of Fe-N-C catalysts and the role of $\mathrm{Fe}, \mathrm{N}$, and $\mathrm{C}$ in the oxygen reduction reaction in acidic medium. ACS Appl. Mater. Interfaces 2019, 11, 35755-35763. [CrossRef]

114. Li, J.; Jia, Q.; Ghoshal, S.; Liang, W.; Mukerjee, S. Highly active and stable Fe-N-C catalyst for oxygen depolarized cathode applications. Langmuir 2017, 33, 9246-9253. [CrossRef] [PubMed]

115. Yuan, R.; Bi, W.; Zhou, T.; Zhang, N.; Zhong, C.A.; Chu, W.; Yan, W.; Xu, Q.; Wu, C.; Xie, Y. Two-dimensional hierarchical Fe-N-C electrocatalyst for Zn-Air batteries with ultrahigh specific capacity. ACS Mater. Lett. 2020, 2, 35-41. [CrossRef]

116. Cammisuli, F.; Giordani, S.; Gianoncelli, A.; Rizzardi, C.; Radillo, L.; Zweyer, M.; Da Ros, T.; Salomé, M.; Melato, M.; Pascolo, L. Iron-related toxicity of single-walled carbon nanotubes and crocidolite fibres in human mesothelial cells investigated by Synchrotron XRF microscopy. Sci. Rep. 2018, 8, 706. [CrossRef] [PubMed]

117. Deng, D.; Yu, L.; Chen, X.; Wang, G.; Jin, L.; Pan, X.; Deng, J.; Sun, G.; Bao, X. Iron encapsulated within pod-like carbon nanotubes for oxygen reduction reaction. Angew. Chem. Int. Ed. 2013, 52, 371-375. [CrossRef] [PubMed]

118. Deng, J.; Yu, L.; Deng, D.; Chen, X.; Yang, F.; Bao, X. Highly active reduction of oxygen on a FeCo alloy catalyst encapsulated in pod-like carbon nanotubes with fewer walls. J. Mater. Chem. A 2013, 1, 14868-14873. [CrossRef]

119. Deng, J.; Ren, P.; Deng, D.; Yu, L.; Yang, F.; Bao, X. Highly active and durable non-precious-metal catalysts encapsulated in carbon nanotubes for hydrogen evolution reaction. Energy Environ. Sci. 2014, 7, 1919-1923. [CrossRef]

120. Matyjaszewski, K.; Xia, J. Atom transfer radical polymerization. Chem. Rev. 2001, 101, 2921-2990. [CrossRef]

121. Matyjaszewski, K. Atom transfer radical polymerization (ATRP): Current status and future perspectives. Macromolecules 2012, 45, 4015-4039. [CrossRef]

122. Peng, C.-H.; Kong, J.; Seeliger, F.; Matyjaszewski, K. Mechanism of halogen exchange in ATRP. Macromolecules 2011, 44, 7546-7557. [CrossRef]

123. Pintauer, T.; Matyjaszewski, K. Atom transfer radical addition and polymerization reactions catalyzed by ppm amounts of copper complexes. Chem. Soc. Rev. 2008, 37, 1087-1097. [CrossRef]

124. Ribelli, T.G.; Lorandi, F.; Fantin, M.; Matyjaszewski, K. Atom transfer radical polymerization: Billion times more active catalysts and new initiation systems. Macromol. Rapid Commun. 2019, 40, 1800616. [CrossRef] [PubMed]

125. Xue, Z.; He, D.; Xie, X. Iron-catalyzed atom transfer radical polymerization. Polym. Chem 2015, 6, 1660-1687. [CrossRef]

126. Gualandi, A.; Mengozzi, L.; Cozzi, P.G. Iron-promoted radical reactions: Current status and perspectives. Asian J. Org. Chem. 2017, 6, 1160-1179. [CrossRef]

127. Zhang, L.; Cheng, Z.; Shi, S.; Li, Q.; Zhu, X. AGET ATRP of methyl methacrylate catalyzed by $\mathrm{FeCl}_{3}$ /iminodiacetic acid in the presence of air. Polymer 2008, 49, 3054-3059. [CrossRef] 
128. Wang, J.; Han, J.; He, D.; Peng, H.; Xue, Z.; Xie, X. Active, effective, and "green" iron(III)/polar solvent catalysts for AGET ATRP of methyl methacrylate with various morphologies of elemental silver as a reducing agent. RSC Adv. 2016, 6, 88490-88497. [CrossRef]

129. Wu, J.; Jiang, X.; Zhang, L.; Cheng, Z.; Zhu, X. Iron-mediated homogeneous ICAR ATRP of methyl methacrylate under ppm level organometallic catalyst iron(III) acetylacetonate. Polymers 2016, 8, 29. [CrossRef]

130. Fu, L.; Simakova, A.; Park, S.; Wang, Y.; Fantin, M.; Matyjaszewski, K. Axially ligated mesohemins as bio-mimicking catalysts for atom transfer radical polymerization. Molecules 2019, 24, 3969. [CrossRef]

131. Mukumoto, K.; Li, Y.; Nese, A.; Sheiko, S.S.; Matyjaszewski, K. Synthesis and characterization of molecular bottlebrushes prepared by iron-based ATRP. Macromolecules 2012, 45, 9243-9249. [CrossRef]

132. Zaborniak, I.; Chmielarz, P.; Wolski, K.; Grzes’', G.; Isse, A.A.; Gennaro, A.; Zapotoczny, S.; Sobkowiak, A. Tannic acid-inspired star-like macromolecules via temporally controlled multi-step potential electrolysis. Macromol. Chem. Phys. 2019, 220, 1900073. [CrossRef]

133. Liu, J.; He, W.; Zhang, L.; Zhang, Z.; Zhu, J.; Yuan, L.; Chen, H.; Cheng, Z.; Zhu, X. Bifunctional nanoparticles with fluorescence and magnetism via surface-initiated AGET ATRP mediated by an iron catalyst. Langmuir 2011, 27, 12684-12692. [CrossRef]

134. Ji, N.; Chen, H.; Zong, G.; Wang, D. Synthesis of novel high oil-absorption resins of poly(methyl methacrylate-butyl methacrylate) by surface-initiated atom transfer radical polymerization using activators regenerated by electron transfer for efficient removal of oil. Polym. Int. 2012, 61, 1786-1791. [CrossRef]

135. Liu, X.; Chen, Q.; Yang, G.; Zhang, L.; Liu, Z.; Cheng, Z.; Zhu, X. Magnetic nanomaterials with near-infrared $\mathrm{pH}$-activatable fluorescence via iron-catalyzed AGET ATRP for tumor acidic microenvironment imaging. J. Mater. Chem. B 2015, 3, 2786-2800. [CrossRef] [PubMed]

136. Wang, Y.; Tian, C.; Jiang, H.; Zhang, L.; Zhu, X. Surface modification of carbon nanotubes by using iron-mediated activators generated by electron transfer for atom transfer radical polymerization. RSC Adv. 2018, 8, 11150-11156. [CrossRef]

137. Al-Roomi, Y.M.; Hussain, K.F. Antiscaling properties of novel maleic-anhydride copolymers prepared via iron (II)—chloride mediated ATRP. J. Appl. Polym. Sci. 2014, 131, 1-10. [CrossRef]

138. Sun, Y.; Du, H.; Lan, Y. Preparation and properties of fluorinated amphiphilic copolymers via iron-mediated AGET ATRP. Iran. Polym. J. 2015, 24, 95-103. [CrossRef]

139. Li, Q.; Zhang, L.; Zhang, Z.; Zhou, N.; Cheng, Z.; Zhu, X. Air-tolerantly surface-initiated AGET ATRP mediated by iron catalyst from silica nanoparticles. J. Polym. Sci. A Polym.Chem. 2010, 48, 2006-2015. [CrossRef]

140. Xu, W.; Cheng, Z.; Zhang, Z.; Zhang, L.; Zhu, X. Modification of SEBS rubber via iron-mediated AGET ATRP in the presence of limited amounts of air. React. Funct. Polym. 2011, 71, 634-640. [CrossRef]

141. Tang, F.; Zhang, L.; Zhu, J.; Cheng, Z.; Zhu, X. Surface functionalization of chitosan nanospheres via surface-initiated AGET ATRP mediated by iron catalyst in the presence of limited amounts of air. Ind. Eng. Chem. Res. 2009, 48, 6216-6223. [CrossRef]

142. Siegwart, D.J.; Oh, J.K.; Matyjaszewski, K. ATRP in the design of functional materials for biomedical applications. Prog. Polym. Sci. 2012, 37, 18-37. [CrossRef]

143. Zaborniak, I.; Chmielarz, P.; Matyjaszewski, K. Modification of wood-based materials by atom transfer radical polymerization methods. Eur. Polym. J. 2019, 120, 109253. [CrossRef]

144. Flejszar, M.; Chmielarz, P. Surface-initiated atom transfer radical polymerization for the preparation of well-defined organic-inorganic hybrid nanomaterials. Materials 2019, 12, 3030. [CrossRef] [PubMed]

145. Lee, N.; Hyeon, T. Designed synthesis of uniformly sized iron oxide nanoparticles for efficient magnetic resonance imaging contrast agents. Chem. Soc. Rev. 2012, 41, 2575-2589. [CrossRef] [PubMed]

Publisher's Note: MDPI stays neutral with regard to jurisdictional claims in published maps and institutional affiliations. 